Synthesis, part of a Special Feature on Implementing Participatory Water Management: Recent Advances in Theory, Practice and Evaluation

\title{
Co-engineering Participatory Water Management Processes: Theory and Insights from Australian and Bulgarian Interventions
}

\author{
$\underline{\text { Katherine A. Daniell }}^{1}$ Ian White $^{2}, \underline{\text { Nils Ferrand }}^{3}$ Irina S. Ribarova $^{4}$, Peter Coad $^{5}$, \\ Jean-Emmanuel Rougier $^{6}$, Matthew Hare $^{7}$, Natalie A. Jones $^{8}$, Albena Popova $^{4}$, Dominique Rollin $^{3}$, \\ Pascal Perez $^{9,10}$, and Stewart Burn ${ }^{11}$
}

\begin{abstract}
Broad-scale, multi-governance level, participatory water management processes intended to aid collective decision making and learning are rarely initiated, designed, implemented, and managed by one person. These processes mostly emerge from some form of collective planning and organization activities because of the stakes, time, and budgets involved in their implementation. Despite the potential importance of these collective processes for managing complex water-related social-ecological systems, little research focusing on the project teams that design and organize participatory water management processes has ever been undertaken. We have begun to fill this gap by introducing and outlining the concept of a co-engineering process and examining how it impacts the processes and outcomes of participatory water management. We used a hybrid form of intervention research in two broad-scale, multi-governance level, participatory water management processes in Australia and Bulgaria to build insights into these coengineering processes. We examined how divergent objectives and conflict in the project teams were negotiated, and the impacts of this co-engineering on the participatory water management processes. These investigations showed: (1) that language barriers may aid, rather than hinder, the process of stakeholder appropriation, collective learning and skills transferal related to the design and implementation of participatory water management processes; and (2) that diversity in co-engineering groups, if managed positively through collaborative work and integrative negotiations, can present opportunities and not just challenges for achieving a range of desired outcomes for participatory water management processes. A number of areas for future research on co-engineering participatory water management processes are also highlighted.
\end{abstract}

Key Words: co-engineering; conflict; multiple objectives; negotiation; participatory process; planning; water management

\section{INTRODUCTION}

Broad-scale, multi-governance level, participatory water management processes are multiplying around the world. Their commonly stated objective is to aid collective decision making and social learning to culminate in mutually acceptable water management actions. Stakeholder participation in water-planning and management processes is equally driven by supranational directives such as the European Union (EU)'s Water Framework Directive (EU 2000, 2002), national policies such as the Australian National Water Initiative (Council of Australian Governments 2004), and championed as a key underlying principle in integrated water resources management (Ker Rault and Jeffrey 2008). Further justification for participatory water management processes stems from the observation that it is increasingly rare that any water manager or single governance structure has the necessary

\footnotetext{
${ }^{1}$ Centre for Policy Innovation, The Australian National University, ${ }^{2}$ The Fenner School of Environment and Society, The Australian National University, ${ }^{3}$ Gestion de l'Eau, Acteurs et Usages (UMR G-EAU), Cemagref, ${ }^{4}$ University of Architecture, Civil Engineering and Geodesy, ${ }^{5}$ Hornsby Shire Council, ${ }^{6}$ Lisode, ${ }^{7}$ UN-Water Decade Programme on Capacity Development (UNW-DPC), United Nations University, ${ }^{8}$ School of Natural and Rural Systems Management, University of Queensland, ${ }^{9}$ College of Asia and the Pacific, The Australian National University, ${ }^{10}$ Marine and Atmospheric Research Division, Australian Commonwealth Scientific and Industrial Research Organization (CSIRO), ${ }^{11}$ Land and Water, Australian Commonwealth Scientific and Industrial Research Organization (CSIRO)
} 
resources to make and implement management actions that meet a majority of needs. This is especially the case in most Western-style democracies where states have decentralized much of their power to regional or local authorities, as well as to private and community-association sectors. Broad-scale participatory processes are rarely initiated, designed, implemented, and managed by one person. Such processes also seldom emerge without some form of collective planning and organization. Instead, multiple actors are commonly involved in developing broad-scale participatory processes. These actors must work together to co-initiate, co-design, and co-implement participatory processes. Here, we term this "coengineering."

To foster sustainable social-ecological systems, we believe that co-engineering processes constitute an area in need of investigation. Our intervention research in this area begins to address some of the gaps outlined in our literature review, and in issues identified by Pritchard Jr. and Sanderson (2002) in seeking sustainability. In particular, we address the political issues of participatory water management processes directly, and provide and report on examples of processes where "individuals, communities and formal organizations engage in the spirit of adaptation and experimentation, by allowing a set of contingent ideas to shape "the gamble' of democratic resource management" (Pritchard Jr. and Sanderson 2002).

Our objective is to investigate co-engineering aspects of participatory water management through "en route" reflection and further ex-post analyses of two research interventions: a participatory riskmanagement process to aid the creation of the regional Lower Hawkesbury Estuary Management Plan on the peri-urban fringe of Sydney, Australia (LHEMP project), and a participatory modeling process focusing on flood and drought risk management in the Sofia region of Bulgaria (Iskar project). In the LHEMP project, private engineering consultants, private planning consultants, researchers, and the local government's estuary manager were the principle participants in the co-engineering process. In the Iskar project, three groups of researchers, private consultants, and a group of regional stakeholders co-engineered the process.

\section{Defining Co-engineering}

The co-engineering of participatory processes is linked strongly to intentional or purposeful action (Checkland 1981, Midgley 2000). The term "engineering" refers to the process of formulating goals, and attempting to design and manage systems to help attain them. However, it is not regarded as a mechanical process, as many (e.g., László 2006) continue to stress. Rather, we consider that: "Engineering is a creative process of synthesizing and implementing the knowledge and experience of humanity to enhance the welfare, health and safety of all members of the community, with due regard to the environment in which they live and the sustainability of the resources employed" (Institution of Engineers 2000).

Therefore, we stress here that engineering as a process is applicable not only to sectors such as civil and mechanical engineering (Dandy et al.2007) but, also, to processes such as knowledge and decision engineering (March 1978). We also consider "coengineering," rather than engineering, as we are interested in collective action, the nature of the social processes associated with engineering practice (Bucciarelli 1994), and the way they influence participatory processes. The coengineering concept is equivalent to attempts to promote collaborative aspects of adaptive management of social-ecological systems by relabeling it adaptive co-management.

We seek here to understand how and to what extent the objectives, conflicts, and social interactions in the project teams, that is, the members of the coengineering process, influence the participatory water management processes they organize. This co-engineering is a form of meta-level engineering and organizational decision-making process that defines the rules and processes for collective choice in water management policy and planning. The collective decision-making process levels and what they correspond to in our research analysis are outlined in Fig. 1.

\section{Background to Co-engineering Processes}

The co-engineering process is defined as the succession of a co-initiation, co-design, and coimplementation phase. These phases are similar to those in the participatory planning process, which we consider here to take the form of a number of 
Fig. 1. Collective decision-making process levels for participatory water management.

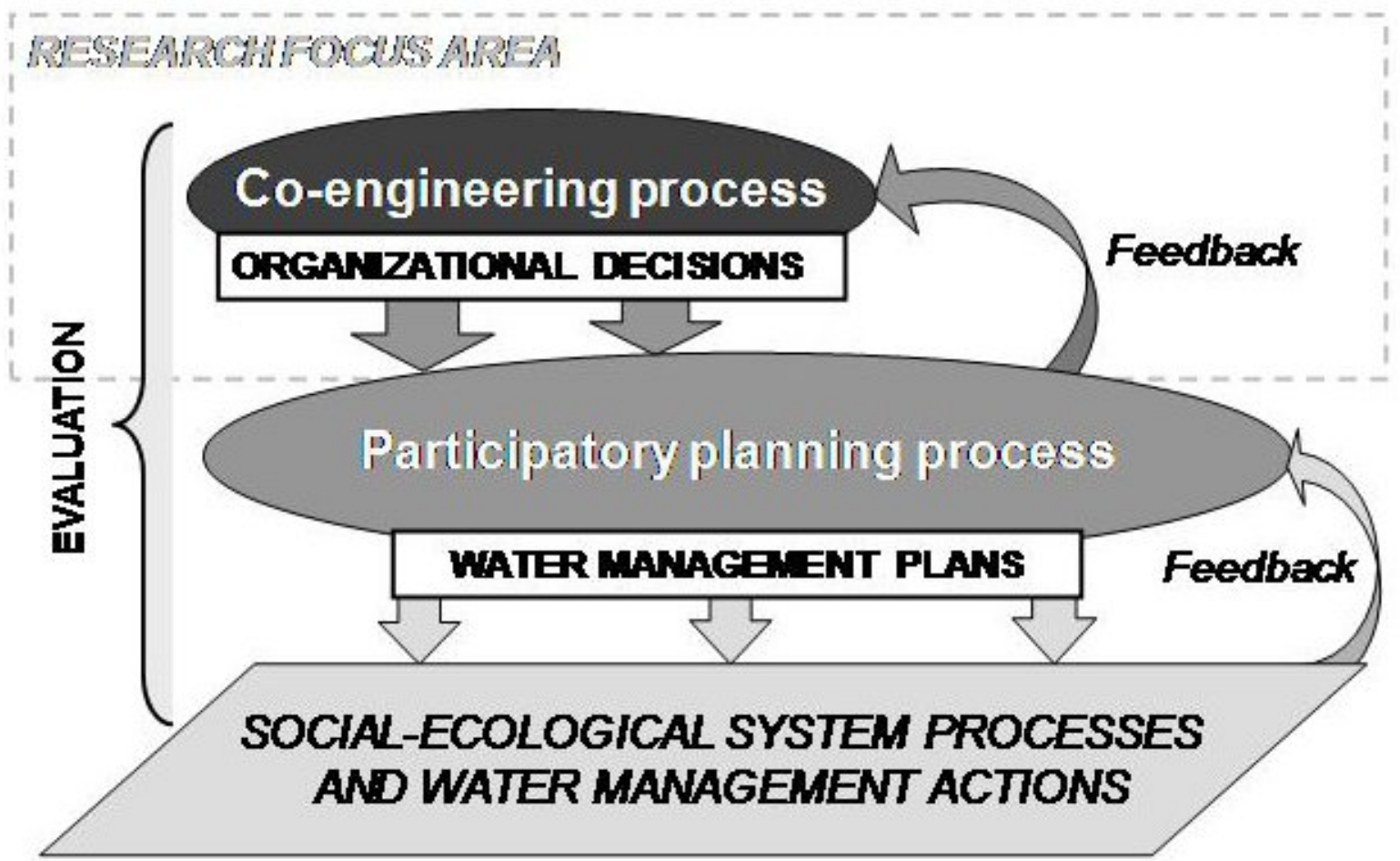

Note: Organizational decisions on how participatory planning is carried out are made at the coengineering level. Water management plans specifying management actions for social-ecological systems result from the participatory planning process level. Feedbacks occur between levels, which could include information or knowledge transfers and provide mechanisms by which inter-system interactions and learning may occur. Evaluation may facilitate feedbacks to be effectively integrated into higher-level processes and lead to greater learning and process improvements.

facilitated or collectively managed stages of situating and formulating problems or issues of interest, through to evaluation of management alternatives, choice, and implementation (Daniell et al. 2006a). The three phases of the co-engineering process are more likely to overlap with, and iterate between, one another, rather than be carried out sequentially. A co-engineered participatory process differs from an engineered one by the presence of a project team working collectively, such as modelers, facilitators, and other project managers who have some shared decision-making power over the objectives, design, choice of methods, and implementation. The co-engineering process ends when the project team disperses, which often occurs when the operational management phase commences after an agreed-upon action plan has been formulated. Typical roles and tasks of the members of the co-engineering process are outlined in Fig. 2.

An extensive literature review was undertaken across a range of domains (Daniell 2008) in search of appropriate theory and previous work on the investigation of co-engineering. However, none of this work directly addressed the co-engineering process for the organization of participatory water management processes. The closest examples include Syme and Sadler (1994), who focus on the use of evaluation in participatory water planning 
Fig. 2. Typical co-engineering process roles and tasks.

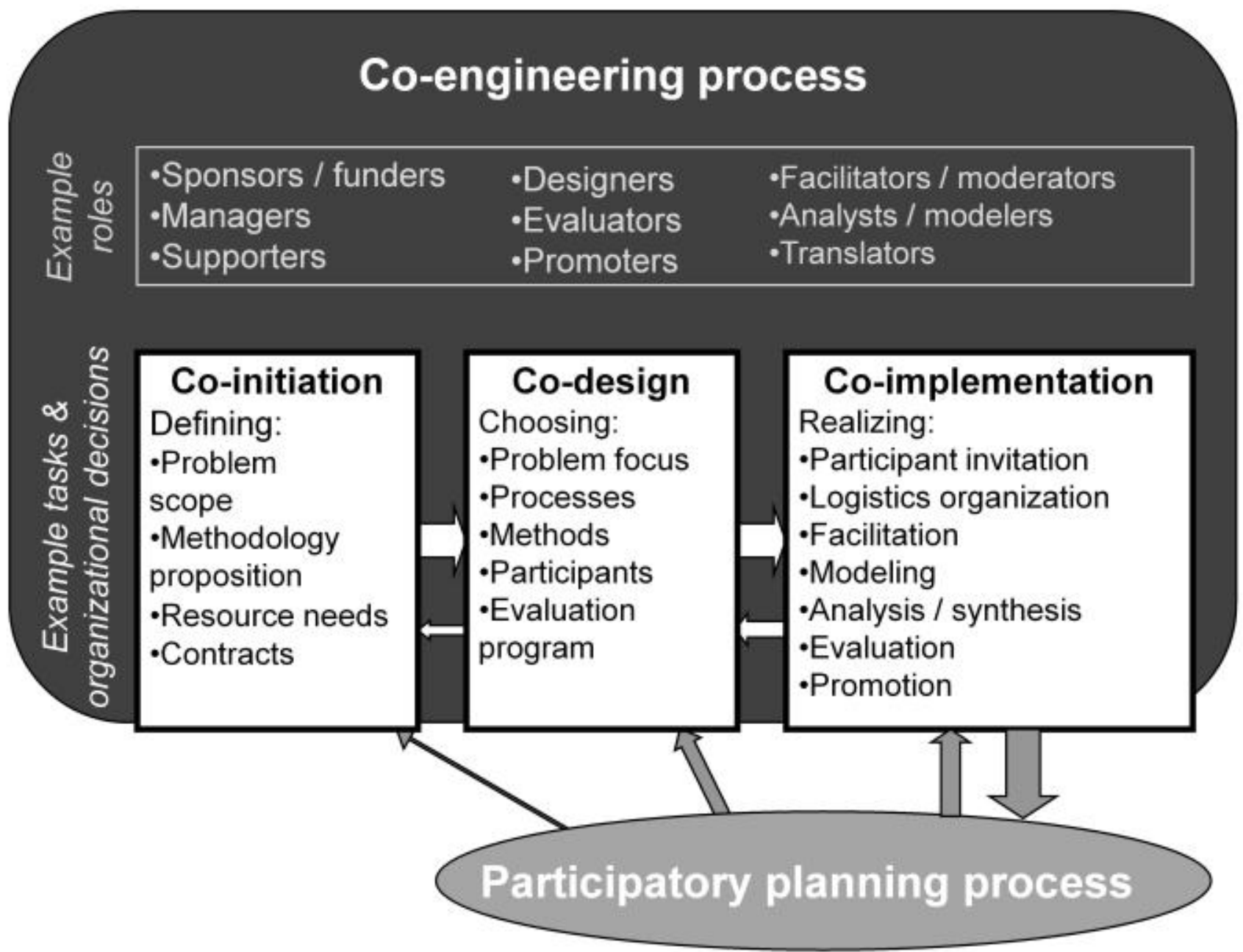

Note: Each phase of the co-engineering process, that is, co-initiation, co-design, and co-implementation, leads on to the next and also to the realization of the participatory planning process. Feedback and iterations between co-engineering phases and during the participatory planning process are possible. Typical magnitudes of influence of processes on each other are represented by varying arrow widths.

processes, and the differences in objectives and roles of practitioners and researchers in organizing these processes. They note potential tensions that may arise between social and instrumental planning objectives of different players in the organization of the participatory process, as well as a number of principles for improving evaluation processes in these settings. Creighton's handbook on public participation (2005) provides a comprehensive overview of phases and tasks required in the design and implementation of public participation processes, with some examples from the water management sector. Creighton also discusses who should be involved, in particular in the United States 
administrative and legal context, and specifies a number of roles to be taken on in the participatory process, such as spokesperson, facilitator, and media-relations specialist, as well as some of the operational tasks required. However, despite mentioning a few potential difficulties that could arise in process organization, little attention is placed on the relational aspects of how potentially diverse people can effectively work together. This is an issue that Syme and Sadler (1994) and other management and engineering-design literature (e.g., Bucciarelli 1994, Katzenbach and Smith 2002, Dandy et al. 2007, Page 2007) note to be significant. The study of relational issues and team-member diversity is largely neglected; however, it can be significant to the group's collective performance and achievement of individual and mutual objectives (Hong and Page 2004). Further discussions on the tensions among individual and collective interests, in particular in interorganizational settings, can be found in the collaboration literature (e.g., Huxham 1996, Thomson and Perry 2006), along with some examples of how collaborations are convened or co-engineered. This literature rarely considers the management of participatory water planning processes. Other references that are relevant to co-engineering processes without explicitly addressing this phenomenon, as well as references that focus on particular aspects of the internal co-initiation, co-design, and co-implementation phases, are provided in Appendix 1.

Although there is a dearth of systematic analysis of all phases of co-engineering processes, there is a broad base of elements available that enable us to study the question of how co-engineering processes effect participatory planning processes for water management. Here, we focus our analyses on the subquestion of how project team-member objectives, interactions, conflicts, and collective choices shape the intervention process and impact the participatory processes designed to aid the management of complex social-ecological systems. We use negotiation theory to analyze specific negotiation episodes in the co-engineering processes of the Australian and Bulgarian cases and the impact of these episodes on the participatory water management processes.

\section{METHOD}

\section{Research Approach and Context}

To investigate how and to what extent the objectives, conflicts, and social interactions in the co-engineering process influence the participatory water management processes, we have predominantly taken an approach based on "intervention research" (Hatchuel and Molet 1986, Hatchuel 1994, Berry 1995, Checkland and Holwell 1998, Flood 1998, Avenier et al. 1999, David 2000, Midgley 2000). However, in-depth analyses and evaluation of the interventions also make the research approach a hybrid of intervention research with case-study based research (Yin 2003). Intervention research is considered by Midgley (2000) as "purposeful action by a human agent to create change." In such an approach, theory is explicitly used to intervene to create collective action from which new insights can be drawn to adjust the theory and intervention en route.

In our research interventions in Australia and Bulgaria, participatory-modeling methodologies were introduced into the co-engineering process for debate, and used to generate actionable knowledge, that is, knowledge that would drive more sustainable management in the Lower Hawkesbury Estuary and Upper Iskar Basin, and aid future interventions in new projects. The participatory-modeling methodologies were based on a methodology originally designed and tested in the European project, AquaStress (Daniell and Ferrand 2006). They were underlain by an interorganizational decision-aiding process model adapted from Tsoukiàs (2007) and Ostanello and Tsoukiàs (1993). This process model outlines elements to be considered through the decisionaiding process: from defining the situation and formulating the problems requiring management, to developing and using an evaluation model to assess potential management alternatives, before finally choosing and recommending the most desired courses of action. We attempt to ensure that these stages will take place in the participatory planning process (Fig. 1); yet, how this is to occur will be dictated by the organizational and operational decisions of the design and implementation phases, which are defined at the level of the co-engineering process (Fig. 1). 


\section{Focus on the Co-engineering Processes and their Impacts}

Our objective here is to understand and demonstrate how aspects of these participatory-modeling methodologies were debated, changed or redesigned, and adapted for implementation by the co-engineering groups in the Australian and Bulgarian cases. We also seek to understand impacts of this co-engineering on the participatory waterplanning process. Part of our collaborative and interdisciplinary-research approach involves using a plurality of approaches to data collection and evaluation within the interventions to investigate the processes and their effects (Levin-Rozalis 2004). Therefore, multi-method evaluation protocols were co-designed and accompanied the coengineering processes of the participatory waterplanning processes in both Australia and Bulgaria to gather as much data as possible on these processes.

\section{Theoretical frame}

Here, we focus on negotiation episodes that are specific co-engineering events where operational preferences and relations between co-engineers can undergo the most rapid changes. They are typically decision-making episodes where divergent or common objectives, interests, and conflicts are also more evident. Decision impacts, or the results of the negotiations, can then be tracked onto the participatory-planning processes. With our focus on negotiation we intend to contribute to the current debate on "re-thinking" participatory processes in natural resources management as ongoing negotiation and conflict resolution processes (e.g., Leeuwis 2000, Leach and Wallwork 2003).

The negotiation and conflict-resolution theory we draw upon and use for our data interpretation are the modes derived from Thomas (1976), Fisher and Ury (1981), and Lewicki et al. (2001). These include the collaborative (integrative), distributive (competing), compromising (sharing), accommodating (appeasing), and avoiding (neglect) modes, which are based on the interaction of the level of importance and energy that negotiation participants place on their own and others' outcomes (Leach and Wallwork 2003). These are shown in Fig. 3. We use the interpretation scheme descriptively to interpret the dynamics of negotiations that occur in the co-engineering processes.

\section{Protocol for Data Collection}

As part of the intervention-research approach taken in the Australian and Bulgarian cases, an evaluation protocol was followed that allowed the systematic collection of rich qualitative and quantitative multisource data on the co-engineering and participatory water management process (Fig. 1). The protocol was based on a range of evaluation, participation, and social-learning literature (Checkland 1981, Argyris and Schön 1996, Bellamy et al. 2001, Marsh et al. 2001, Ferrand 2004, Siebenhüner and Barth 2005, Ferrand and Daniell 2006, Jones et al. 2009) and included a range of guiding questions to gather information. For example, guiding questions for the "co-design" part of the co-engineering process (see Fig. 2), included: Who is involved in the co-design process? What are their objectives, stakes, resources and roles? To what extent do divergences or commonalities exist? To what extent do the codesigners work effectively together? Have there been changes since the co-initiation process? If so, changes on what and why? A more complete description of the evaluation-protocol development and procedures is beyond our scope, but is available in Daniell (2008). For our purposes, we will describe a number of methods of data collection used within the protocols that are relevant to our focus of how project team-member objectives, interactions, conflicts, and collective choices shape the intervention process and impact the participatory processes design, as well as how we sought to code and interpret this data relative to the negotiation theory.

\section{Data and Interpretation}

For both intervention cases, a dedicated formal evaluation was conducted by an external observer who attended some design meetings and all of the participatory planning workshops (Jones 2007, Vasileva 2007, Jones et al. 2009), but who was not a member of the project team responsible for the participatory process and its outcomes. These evaluators were responsible for preparing and administering the participant questionnaires at the end of each participatory workshop, which had been developed in collaboration with some of the coengineers. The questionnaires typically included between 10 and 25 open- and closed-answer questions, which allowed participant-perceived impacts of the co-engineering process to be elicited. For example, if a co-engineer had an objective of 
Fig. 3. Negotiation modes.

Importance of own outcomes

\begin{tabular}{|c|c|}
\hline $\begin{array}{l}\text { Distributive } \\
\text { Competing: "win-lose" }\end{array}$ & $\begin{array}{l}\text { Collaborative } \\
\text { Integrative: "Win-win" }\end{array}$ \\
\hline \multicolumn{2}{|c|}{$\begin{array}{c}\text { Compromising } \\
\text { Sharing }\end{array}$} \\
\hline $\begin{array}{l}\text { Avoiding } \\
\text { Neglect: "lose-lose" }\end{array}$ & $\begin{array}{l}\text { Accommodating } \\
\text { Appeasing: "lose-win" }\end{array}$ \\
\hline
\end{tabular}

Note: Adapted from Leach and Wallwork (2003), Thomas (1976), Fisher and Ury (1981), and Lewicki et al. (2001).

creating a workshop to enhance participant interaction and learning, questions probing participants on what they had learned during the workshop could help to gauge the efficacy of the participatory processes' co-engineering on this aspect. Evaluators also recorded observations on participants' and co-engineers' behaviors and relations to each other. Informal interviews were also carried out to further investigate observations of interest. We paid particular attention to the phenomenon of discordance, i.e., participants manifesting different objectives or interests, or discomfort, i.e., negative body language or verbal complaints, in each others' presence. For example, body language of a "blocking or defensive" type (Pease and Pease 2005) could signify conflicts or their impacts. Evaluators' impressions and interpretations could also be re-analyzed by the other co-engineers and authors of this paper ex-post using video recordings.

Further data on co-engineering negotiations and conflicts was obtained through en route and ex-post analyses, personal reflections, and reporting performed by a number of the participating coengineers. For example, the first author, who participated as a researcher, specialized in participatory process design in the two cases and developed "experimental reports" (Hatchuel and Molet 1986) on the interventions, which included maintaining notes on co-engineering negotiations. This included keeping records of what was said and the co-engineers' personal feelings about the progression or diffusion of conflicts, including whether they led to learning about their own and others' objectives. If such learning was evaluated to have occurred on both or multiple sides of a negotiation, then this is then interpreted as a move toward the collaborative mode of negotiation (Fig. 3 ). The lead author also carried out in-depth semidirective interviews with one other co-engineer in the Australian case (1.5 hrs) and four co-engineers in the Bulgarian case (ranging from 1.5 to $6 \mathrm{hrs}$ ) to further delve into the negotiations and conflicts of the co-engineering groups. They were audiorecorded but only partially transcribed. These 
interviews supplemented and allowed crossexamination of personal reports, observations, and the process documentation analyses of both cases, i.e., of scoping documents, e-mail correspondence, meeting minutes and notes, debriefing session records, project team-member interviews, participant and facilitator evaluation questionnaires, photos, reports, and some audio and video recordings of workshops. In the Iskar project, many of the above data sources were translated into English by Bulgarian colleagues. The co-engineering episode interpretations and impacts presented here have been triangulated (Yin 2003) as far as possible using a variety of these sources, and interpretations crossverified by a number of the co-engineering groups' members and external evaluators.

\section{SELECTED RESULTS ON THE CO- ENGINEERING PROCESSES}

Here we present examples to illustrate how and to what extent the objectives, conflicts, and social interactions of the members of the co-engineering process influence the participatory water planning processes. From the two interventions, many possible examples could have been highlighted. We have chosen to present just two co-engineering events where negotiations and decisions were focused on different bases. (1) The first is a negotiation with a "normative" and "relational" basis, where the question of participant exclusion or inclusion from participatory workshops in the Australian case was treated, and (2) the second is a negotiation with a "substantive" basis, where the question of changing the problem scope was raised in the Bulgarian case.

We will present the context for each example, outline and interpret the co-engineering negotiation episode using the previously defined "negotiation modes" of the chosen theoretical frame, and evaluate impacts of this event on the participatory water management process. Further information on other co-engineering events in each of the interventions is provided in Appendix 2. Table 1 provides a brief summary of some of the key characteristics of the intervention cases.

\section{Negotiating Participant Inclusion and Exclusion in Regional Planning Processes: Co- engineering the Creation of the Lower Hawkesbury Estuary Management Plan in New South Wales, Australia}

\section{Context: process background}

In Australia, natural-resources ownership is vested with the state and territory governments by the Australian constitution. The planning and management of water and land resources are carried out by multiple state agencies under state legislation. Local governments, which are the principal means for communities to express their identity, enhance their wellbeing, and care for their local environments, rely on both local community charges and the largess of state governments to carry out these functions. Under New South Wales (NSW) Estuary Management Program guidelines (NSW Government 1992), estuary management plans are developed by local governments and implemented in collaboration with estuary management committees. These committees include representatives from state and local governments, regional agencies, industry, residents, estuary user groups, NGOs, and academic institutions. The local government may choose to develop the plans largely in-house, or put out a public tender for the work to be carried out by consultants. Plans cover specific estuaries within their defined water catchments (Hornsby Shire Council 2006).

The Lower Hawkesbury River Estuary lies on the northern fringe of the Sydney Metropolitan Area in eastern Australia. Despite its proximity to the largest urban centre in the country, the peri-urban estuary and its surrounds are partly within a national park and remain an area of immense natural beauty with high ecological and indigenous and nonindigenous cultural values. The heavily forested catchments, steep cliffs and gorges, deep waterways, and secluded bays and beaches support high levels of biodiversity, local communities, industries, and recreation (BMT WBM 2007). Future drivers such as rapid population growth and climate change may have major negative impacts on the area if not managed successfully.

In 2006, only 50 percent of the estuary and its tributary creeks had been covered by estuary management plans developed on the NSW Estuary Management Program guidelines. The region's 
Table 1. Comparative co-engineering process characteristics.

\begin{tabular}{|c|c|c|}
\hline Characteristic & Australian process & Bulgarian process \\
\hline Process type & Management-driven, supported by research & Research-driven to support management \\
\hline $\begin{array}{l}\text { Principle shared } \\
\text { objective }\end{array}$ & Create a regional estuary management plan & $\begin{array}{l}\text { Test a multi-level participatory modeling } \\
\text { process for joint flood and drought risk } \\
\text { management }\end{array}$ \\
\hline $\begin{array}{l}\text { Principle co-engineering } \\
\text { institutions }\end{array}$ & $\begin{array}{l}\text { Local government water managers; university } \\
\text { researchers; private environmental engineering } \\
\text { consultants }\end{array}$ & $\begin{array}{l}\text { University researchers; government institute } \\
\text { researchers; private research consultants; } \\
\text { stakeholder group }\end{array}$ \\
\hline $\begin{array}{l}\text { Participatory process } \\
\text { stakeholder and } \\
\text { administrative level } \\
\text { inclusion }\end{array}$ & $\begin{array}{l}\text { State government departmental representatives; } \\
\text { local government councilors; managers, planners, } \\
\text { and scientists; national environmental NGO; } \\
\text { Catchment Management Authority } \\
\text { representative; regional associations, industries } \\
\text { and commerce; regional water-agency managers; } \\
\text { local residents }\end{array}$ & $\begin{array}{l}\text { National Ministers and departmental } \\
\text { representatives; national NGOs, association } \\
\text { representatives and water experts; Water } \\
\text { Basin Directorate representatives; regional } \\
\text { mayors; regional water-agency manager; } \\
\text { municipal representatives; local residents }\end{array}$ \\
\hline $\begin{array}{l}\text { Participatory process } \\
\text { (and average number of } \\
\text { participants at each } \\
\text { workshop) }\end{array}$ & $\begin{array}{l}\text { Three workshops over } 4 \text { months with } 38 \\
\text { participants (average of } 22 \text { per workshop) }\end{array}$ & $\begin{array}{l}\text { Two sets of interviews and } 15 \text { workshops } \\
\text { over } 1 \text { yr with approximately } 135 \text { participants } \\
\text { (first } 13 \text { workshops: average } 8 \text {; last two } \\
\text { workshops: average 26) }\end{array}$ \\
\hline
\end{tabular}

stakeholders considered this insufficient to manage the lower estuary in a coherent and integrated manner. The Hawkesbury Nepean River Estuary scoping study report (Kimmerikong 2005), commissioned by the regional Catchment Management Authority, recommended that to improve effectiveness, estuaries should be managed by a "whole-of-estuary" approach, rather than by managing portions based on local council-area boundaries. In early 2006, a proposal to create and fund a regional "Lower Hawkesbury Estuary Management Plan" (LHEMP) was put forward by the Hornsby Shire Council (HSC), an elected local government with jurisdiction over part of the estuarine area. It was proposed that the LHEMP be formulated in close cooperation with the Gosford City Council (GCC), which also has jurisdiction over a large part of the proposed plan area. The proposed LHEMP was to be one of the first broader scale estuary management plans to be created in Australia.

The co-engineering process of the LHEMP's development has been studied from the first meetings between the HSC's estuary manager and a researcher from the Australian National University who was interested in developing multilevel participatory processes as a means of improving water planning and management practices. Their interests in using a participatory planning approach for estuarine management appeared to be mutually beneficial. The results of these meetings were that: (1) the researcher would offer her expertise in aiding the design, management, and coordination of the evaluation of the participatory section of the planning process free of charge to HSC, and (2) a written contractual requirement of the project manager sought through public tender was to support and integrate the results of the participatory process into the LHEMP in collaboration with the researcher. This tender (HSC 2006) stipulated that the participatory planning process was to actively involve a large range of stakeholders, including service agencies, industries, community associations and residential representatives, and state government representatives who are also responsible for certain domains of estuarine management. 


\section{Context: process proposal outline}

The proposed participatory process for the plan creation outlined in the tender was largely based on the researcher's methodology outlined in Daniell et al. (2006b) and Daniell and Ferrand (2006). The process was to include a series of between two and four stakeholder workshops and an external document review that would cover much of the scientific and management information required under the NSW Estuary Management Program guidelines (NSW Government 1992). One potential respondent to the tender then negotiated with the researcher to include three participatory stakeholder workshops in his tender response. This respondent from a consortium of private environmentalengineering consultants, BMT WBM, and planning consultants, SJB Planning, became the contractual project manager selected by HSC. During the first project-initiation meeting, a new key procedural interest was then voiced by the HSC estuary manager. He suggested that the Australian and New Zealand Standard for Risk Management (Standards Australia 2004, 2006) be used as the basis for the LHEMP process, underlying the participatory and external analysis activities.

\section{Context: team composition}

Throughout this planning project, the key coengineers of the participatory process were considered to be the HSC estuary manager, the contracted project manager, and the researcher. These co-engineers all possessed a strong will to drive the sustainable management of the estuary and to enhance its environmental quality. On top of this shared objective, each of these co-engineers also managed or funneled the work, interests, and a number of other objectives of their associates into the central co-engineering process. For example:

- The estuary manager worked and consulted with his superiors and colleagues in HSC and the estuary manager of GCC, as well as a number of key state agency staff and stakeholders, to maintain political will and financial support for the planning process.

- The project manager organized the inputs and activities of a group of consultants in the planning process, including their scientific and management-review inputs and briefing them for performing small-group facilitation roles, to ensure their team's efficiency and effectiveness in carrying out their contractual obligations.

- The researcher coordinated the activities of the external evaluators monitoring the process, and gathered knowledge from colleagues for the design and development of participatory methods for the workshops, to develop a theoretically coherent and wellevaluated participatory modeling-intervention case for her research.

The project's co-initiation phase lasted approximately 6 months, followed by 2 months in the preliminary co-design phase, and 4 months from the beginning to the end of the participatory workshops in an adaptive co-design and coimplementation phase. Approximately 15 associates performed visible co-engineering roles (see Fig. 2), especially participating in project meetings or in the co-implementation tasks of the participatory workshops (refer to Appendix 2). The final participatory process included three workshops, the contents and participants of which are outlined in Appendix 3. The final version of the plan was accepted by both local governments, HSC and GCC, in March 2009, following the period of compulsory public exhibition of the draft plan for public comment.

\section{Negotiation episode: participant inclusion or exclusion}

The first workshop involved a broad range of agency and community stakeholders, and successfully elicited participants' values and issues of the estuarine region. The participatory methods chosen had effectively reduced confrontation between community members and a water and wastewater agency over the discharge of tertiary treated sewerage water to the estuary (Daniell 2007). Participants had been informed that they would be invited to participate in two further workshops to prioritize their objectives for estuary management and develop and assess strategies to achieve them. A project meeting, following this workshop and a month prior to the second workshop, was held at HSC to determine the details of the combined synthesis report and the contents of the next workshops. It was attended by the three key coengineers, as well as an environmental scientist associate of the project manager. 


\section{Distributive mode}

In the meeting, the project manager proposed that the next workshops were not required. He said that an enormous amount of information had been gathered from the participants already, and that it would be more efficient to carry out the rest of the risk-management process and plan development inhouse. The researcher, surprised at this suggested change of plans, reacted strongly against the suggestion. She argued that such a change would be inefficient and that it contradicted a previous statement by the project manager that using a participatory process would allow the participants to do the work and make the decisions that consultants would usually have to justify by using multi-criteria analysis (Jones 2007). The project manager acknowledged this and was prepared to keep at least the third planned workshop on strategy building, but proposed that the second on risk assessment could be removed as it would be too difficult to perform in a large participatory group. The researcher replied that she thought it would be possible to design an efficient and effective participatory method to perform the risk assessment in a big group. She contended that having larger numbers of participants would increase the knowledge and competency required to complete the risk assessment effectively. The project manager then suggested that a small group of experts, including some from HSC, could be used to create a greater knowledge base. The researcher pointed out that such an approach would have problems of legitimacy among the stakeholders, as risk assessment is a very subjective process. She suggested that the people required to legitimize the plan should be involved in the assessment, especially for the vague risks in the estuarine context. We see here that the negotiation was clearly in a distributive mode, and had adopted a "positional bargaining" approach (Fisher and Ury 1981). Both the project manager and the researcher were trying to defend their own positions: for the project manager, that there should be minimal participation; and for the researcher, that the workshops should involve all stakeholders. This occurred without their underlying personal interests and needs being articulated.

\section{Compromising/collaborative mode}

Throughout this debate, the estuary manager had remained silent, carefully listening to both the project manager and researcher. Following the last discussion, he reflected to the group his need to have state-agency support for the plan, given that they would eventually fund actions arising from the plan. He suggested that the agencies would appreciate being involved in the risk assessment, and that maybe an "agency-only" workshop could be planned. The researcher agreed that it could be an option, but that community backlash could prove to be a problem when the community representatives found out they would be excluded, potentially leading to their rejection of the risk assessment. The estuary manager replied that although such backlash was a possibility, he thought that most community members would understand the decision, even if they were not pleased about it, as they recognized the necessity of agency support for the plan. He also added that an "agency-only" workshop would likely provide a "safer" place for agency representatives to share their real concerns, as meetings with the community members could be confrontational. At this point the project manager suggested directly giving the estuary manager the decision of selecting one of four options: (1) no workshop, (2) an "expertgroup" workshop, (3) an "agency-only" workshop, or (4) a workshop with everyone. The researcher agreed with the suggestion. The estuary manager chose the "agency-only" option, and the discussion moved on to who would be invited. In the end, residents and representatives of local user associations were to be excluded. Representatives of all state and local governments, the Water Authority, Catchment Management Authority, and industry and commercial representatives would still be invited, as they were seen to have the potential financial resources necessary to implement the plan.

Further interpretation and ex-post analysis of the negotiation episode

This last phase of more collaborative and less confrontational form of negotiation appears to have stemmed from the estuary manager making explicit his need for the plan to be legitimated by stateagency staff to ensure funding, as well as his recognition of the needs of the agencies and community members. By expanding analysis of this negotiation, using data on the negotiation from the researcher's experimental report, an ex-post analysis of project documents and e-mails, and semidirective and informal interviews of the researcher and estuary manager, we see that both the project manager and researcher highly respected the estuary manager and his needs. This appears to have incited both to become more open to 
compromise or finding a solution for the workshops that would meet his needs as well as their own. Upon hearing the need for agency-funding support clearly articulated, the researcher recognized the overall needs for the process differently and started to rethink her own fundamental needs and objectives. As her thesis required "a participatory process" but not necessarily one with everyone participating at all meetings, she saw that she would be able to change her own objectives satisfactorily if either the "agency-only" workshop or the "expert-group" workshop was chosen. At the end of the negotiation, both the researcher and project manager trusted the estuary manager to make the final decision, as they both knew that the estuary manager recognized their own needs and interests for the participatory process. They also considered that he would make a decision in the best interest of the estuary and the local government, after having assessed the likely impacts of different courses of action outlined in the discussion.

\section{Impacts of the negotiation episode}

This negotiation episode resulted in a number of impacts apparent from evaluation data, both at the level of the co-engineering process and at the level of the participatory planning process (refer to Fig. 1). At the level of the co-engineering process, some social learning occurred among the participating coengineers. The adjustment of the researcher's own objectives and perspectives on the participatory process that occurred in the second stage of the negotiation and following it represents one piece of evidence for this social learning. However, the participatory process evaluators also saw that the first confrontational stage of the negotiation had damaged relations and trust between the project manager and researcher. For example, the principal external evaluator noted tension between the two in the second workshop, where the project manager's body language appeared partially "blocking" or negative toward the researcher, even if all oratory remarks and work together remained cordial. The researcher also admitted in an interview with the external evaluator that her trust in the project manager had been reduced, as she did not understand his needs or objectives, but that she was making conscious attempts to try to improve their relationship.

From analyses of e-mail correspondence during the participatory process organization and interviews with the project manager and researcher, the researcher realized after the second workshop that the project manager had been under extreme time pressure, owing to a number of other consulting projects he was concurrently managing. Thus, it appeared that the reasons for wanting to delete the workshops were because of time constraints, and the project manager not being able to dedicate sufficient work efforts to the workshops and to understanding the Risk Management Standard, rather than any fundamental rejection of the participatory process. This furthered understanding, and demonstrates the indirect issues that can be encountered in co-engineering processes.

At the level of the participatory planning process, some of the hypothesized positive and negative impacts of the final decision to hold an "agencyonly" workshop were observed. First, as suggested by the estuary manager, external monitoring showed the choice of inviting only agency representatives created a "safe space" that was conducive to open, directed discussion of management issues. Participant responses to an open evaluation question, namely, "Overall, what did you like about the workshop?" related to this issue included: "good, honest discussion," "openagency discussion," "different points of view," and "[the risk assessment] matrix forced you to work out or question each risk in detail." These responses provide support for the view that agency representatives perceived the workshop provided them with opportunities for frank exchange on management issues, a view further supported by the majority of responses to one of the quantitative questions (to which 13 out of 20 participants responded on a five-point Likert scale-strongly agree, agree, neither agree or disagree, disagree, strongly disagree), where 11 respondents "agreed" that the activities in the workshop helped them to share their views and opinions with others, and the other two "neither agreed nor disagreed." This degree of agreement compared favorably with the other perceived outcomes of this workshop (Daniell 2008).

However, as predicted, negative "backlash" and potential disempowerment of community representatives from the workshop were also observed. One community member phoned the project manager to voice her disappointment about her exclusion before the second workshop, and asked if she could still attend. Her request was declined. When the community member came to participate in the third workshop, she described in her evaluation 
questionnaire how being excluded from the second workshop had been a "very disempowering experience." She added in the final suggestions section that the government-agency workshop could still have gone ahead, but that the process need to be explained differently from how it was in the invitation letter, so that the members of both existing local estuary-management committees were not disempowered but retained ownership of the process. Having been contacted by the estuary manager about this participant's disappointment before the third workshop, the researcher and evaluator were able to focus some of the monitoring activities for the evaluation program on the previously excluded participants, to help to mitigate and improve feelings over negative impacts. For example, the evaluator held an informal interview with the community member during one of the workshop breaks to allow the participant to make her feelings about the process known. During facilitation activities, the researcher made extra efforts to encourage her, and other previously excluded participants', participation in the workshop, showing that their contributions were greatly valued. This attention seems to have contributed to the community member's final thought on her questionnaire that "I am sure the process was well intentioned and I would like to see adoption of the plans by government agencies and the community."

\section{Negotiating Late Problem-Scope Changes: Co- engineering a Participatory Flood and Drought Risk-Management Process in the Upper Iskar Basin, Bulgaria}

\section{Context: process background}

Extreme climatic conditions, such as large floods and extended drought periods, have occurred over recent years in Bulgaria and the Upper Iskar Basin in the region of the nation's capital, Sofia. There has been debate on whether these "new" conditions are a consequence of global climate change or normal variability (Knight et al. 2004, Kundzewicz and Schellnhuber 2004). Water management in such a context has presented many challenges, not just because of these extreme events or seemingly natural hazards, but also because of the transitory nature of the country's social and political spheres following the fall of the communist regime in 1989, and the need to deal with its legacy of heavy industry, wide-spread pollution, and infrastructure- system issues (Hare 2006). With its recent ascension into the EU, Bulgaria must now improve management of its water resources and resolve associated use conflicts among industrial, urban, agricultural, ecological, and other human needs, in line with EU legislation such as the Water Framework Directive (European Union 2000). Responsibility for water management in Bulgaria lies at the national and river-basin levels, as outlined in the Bulgarian Water Act (1999), which is predominantly in line with the Water Framework Directive (Dikov et al. 2003).

To aid the improved management of water in the Upper Iskar Basin, which is part of the Danube River Basin, in the Bulgarian water management framework a number of initiatives were proposed as part of the European Integrated Research Project, AquaStress. These included a participatory riskmanagement process to attempt to support regional co-management of floods and droughts (Ribarova et al. 2006). The co-initiation, co-design, and coimplementation of this process is our focal coengineering process. The general needs for this initiative had been identified by the Local Stakeholder Public Forum (LPSF), a diverse group of stakeholders from the Upper Iskar Basin ranging from national-level policy makers to citizens' group representatives, who were brought together by researchers as part of the AquaStress project. Two of their seven key defined needs included learning to cope better with the crises produced by floods and droughts, and to improve inter-institutional coordination. The Bulgarian regional partner coordinating this group had then publicized these stakeholder research needs to researchers in a major project meeting, and a French research director had spoken to her about a research proposal that would aim to fit these needs.

The research proposal was to test the "Participatory Modelling for Water Management and Planning" water stress-mitigation option (Daniell and Ferrand 2006) which had been previously defined as part of the AquaStress project, with a focus on operationalizing a participatory process for developing and assessing strategies to conjointly manage the region's flood and drought risks. The proposition was also further discussed and accepted by the LPSF in a meeting in Bulgaria, and tested in an adapted form with a group of Bulgarian students during part of the AquaStress Summer School program in June 2006 (Rougier 2006). 


\section{Context: process proposal outline}

The formal design proposal of the "Living with Floods and Droughts" participatory-modeling project for the Iskar Basin was then collaboratively created during a meeting in Paris in July 2006 by three European researchers from outside Bulgaria: (1) the research director who had originally put the proposal forward, (2) a Master's student on an internship with the research director, and (3) a private research consultant who specialized in participatory-process management for enhancing social learning (Ferrand et al. 2006, Hare 2006, Rougier 2006). The process design was based largely on the process phases outlined in Daniell and Ferrand (2006), with the "System, Actors, Solutions (SAS) Integrated Model" (Ferrand et al. 2007) and the "Group Model Building" approach outlined in Pahl-Wostl and Hare (2004) driving choices on the internal modeling components. The process was to include six series of workshops and two rounds of interviews with six groups of participants from around the Upper Iskar Basin. These included: (1) a group of citizens and a group of local authority stakeholders from the municipality of Elin Pelin, principally affected by floods, (2) a group of citizens and a group of organized stakeholder representatives from Sofia, affected by both floods and droughts, (3) a group of local authority representatives from the municipality of Samokov, affected by droughts, and (4) a group of national-level policy makers concerned with all aspects of water policy, including managing flood and drought risks. Because of the "research-driven" nature of the project, the participants were to be paid under "research participation contracts" from the AquaStress project, to help ensure their continued participation in the long process and offset their costs of attendance. The Bulgarian regional partner accepted the proposal and found the designers an English-speaking Bulgarian trained in facilitation, who would be paid by the AquaStress project, to help support the management and implementation of the process.

\section{Context: team composition}

There were a number of co-engineers participating in the initial co-initiation and co-design phases of the participatory water management process, although they were principally convened in two groups: (1) one by the Bulgarian regional partner, and (2) one by the research director. First, the Bulgarian regional partner carried most of the responsibility for the organization of on-the-ground activities and logistics in Bulgaria, because of the need for Bulgarian to be spoken, and was the main communicator with the researchers from outside Bulgaria. However, this role was planned to be subsumed for the participatory-modeling process by the Bulgarian facilitator contracted to work on the project. The Bulgarian regional partner was further supported by her University dean who also participated in AquaStress project meetings, as well as a colleague from her university paid by the AquaStress project to evaluate all the Iskar Basin project activities. The regional partner was also the funnel for information and needs from the LPSF's co-engineering work. Second, the research director was responsible for managing the research side of the participatory-modeling process, in particular its design and evaluation, and obtaining a number of research outcomes for the AquaStress project. He directed a Master's student who was contracted after his studies to keep working on the project, and convened the work with the private research consultant.

The co-initiation phase of this project lasted approximately 4 months, followed by 3 months in the co-design phase, before commencement of the 1 -yr long participatory process, accompanied by ongoing co-design and co-implementation. The total number of co-engineers then increased and varied through the ongoing and adaptive co-design and coimplementation phases of the process, which lasted just over a year. Up to 30 people played at least one role at some point in the co-engineering process (see Appendix 2). An outline of the resulting participatory water management process and methods used for implementation can be found in Appendix 3.

Through the co-design and co-implementation processes, on the Bulgarian side, another facilitator was contracted by the regional partner to help with large workshop implementation and interviewing procedures. The regional partner and several of her students also interviewed stakeholders. Just before the fourth series of workshops, the trained Bulgarian facilitator abruptly left the process to take up a longer-term job, and the regional partner decided to take over the facilitation and ongoing co-design duties herself. She also asked another of her colleagues at the university for extra operational support for the workshop organization. On the external research side, during the on-going codesign and co-implementation activities, there were 
also increasing numbers of co-engineers involved in the process. A colleague of the research director helped with modeling and data synthesis following the workshops, the director's institutional manager became interested in the process after attending a number of AquaStress meetings and internal briefings, and a PhD student of the director was asked to become involved in the process from the fourth workshop series onward.

\section{Negotiation episode: problem scope changes and workshop organization}

The negotiation episode of interest in this section took place prior to the final workshop of the participatory-modeling process, almost a year after the start of the process. The workshop had originally been designed to be an assessment of flood and drought management strategies using a multicriteria software program developed in another part of the AquaStress project. However, the PhD student had doubts that this multi-criteria assessment would be the best design because of: (1) a lack of different clearly defined strategies that had been developed through the other stages of the project, and (2) her belief that the process should produce something useful for participants so that they would see the benefits of participatory processes and not be disappointed by the academic outcomes (Barreteau et al. 2010).

She first raised these doubts over the direction of the process at the debriefing meeting of the second to last workshop with the regional partner, facilitator, contracted researcher, and a number of the regional partner's colleagues. At this meeting, it was clear everyone supported the idea of making the last workshop interesting, although they were not sure how, so that the participants would appreciate it. These issues of creating a positive end to the process were discussed further among the research team and the French institution's AquaStress project manager who arrived the next day and was taken on a field trip to see some of the stakeholders and hear stories about their recent flood events. Having met these citizens and seen their real-life difficulties, he supported the idea of attempting to improve the participants' on-theground situation and capacity to cope with floods. At this stage, the Bulgarian regional partner mentioned the possibility of there being Bulgarian European structural funds available to help with regional development, and wondered whether the last workshop could be organized to be the first stage of designing a proposal to obtain some of these funds for flood mitigation and adaptation projects.

A week later, the regional partner had traveled to Brussels for a meeting with the European Commission. She informed researchers that there would be structural funds for risk management and, in particular, flood management. She asked whether the final workshop could create an action plan for the flooded region, which was also on the list of priority regions for structural funding. It is the negotiation and decisions following this specific proposal that we wish to analyze.

\section{Distributive and compromising modes}

In France, the $\mathrm{PhD}$ student was attracted to the action-planning proposal. The research director was less enthusiastic about it when they met to discuss it. He stated that some of the original research objectives and the contractual commitments for the AquaStress project would not be able to be achieved if the program was changed. In particular, (1) the multi-criteria analysis tool created in the AquaStress project would not be tested, (2) the planned area for the Action Plan (Elin Pelin) would not be of as much interest for all of the stakeholders involved in the project, and (3) drought management would not be treated to the same extent as had been planned. Therefore, this change would constitute a major alteration in the problem scope of the process from co-management of floods and droughts, to just floods. Considering these issues and the other more positive aspects of the proposal, the research director and $\mathrm{PhD}$ student went to discuss the proposition with the AquaStress project manager. The project manager viewed this proposed change positively, as he understood the regional issues at stake, having recently been to see the problems firsthand, and hoped that it would lead to greater Bulgarian support and appropriation of the participatory process. He also stated that he trusted the regional partner's and the $\mathrm{PhD}$ student's judgment and, therefore, would support the proposal if the research director wanted to adopt it. The research director finally decided to accommodate the views of the rest of the project team and adopt the proposal, with certain provisos, despite his concerns. This was a significant compromise on his scientific research objectives. 


\section{Collaborative mode}

Following this decision, the research director's work with the $\mathrm{PhD}$ student became more collaborative, as they collectively sought possible solutions for participatory-workshop design and method choice to meet as many of their objectives as possible. After their discussions, the $\mathrm{PhD}$ student attempted to design a process for the workshop that would achieve a variety of remaining objectives, both scientific and operational. The research director made minor additions to the workshop design and sent it to the Bulgarian regional partner.

\section{Distributive mode}

The regional partner's reaction to the design of the workshop was initially lukewarm, as she did not appreciate the plan to divide the participants into subgroups to deal with certain sectors of the flood planning. The subgroups proposed were: (1) construction and infrastructure, (2) planning, management, decision infrastructure and monitoring, (3) education, empowerment and capacity building, (4) crisis management and action plan, and (5) remediation and insurance. She also thought that other activities related to the AquaStress objectives and completing the work required for the structural funding plan were unnecessary. The French research director wrote a rebuttal to her e-mailed reaction, reviewed by the $\mathrm{PhD}$ student, pointing out that her arguments would support neither her own goals nor the needs of the AquaStress project.

\section{Accommodating mode}

Giving in to the researchers, at least for the time being, the regional partner wrote back, "We will do the workshop as you wish. I shared with you my 'feelings' about it, but as I repeated many times before - this is your study, you are the experts. I provide only local help." She also mentioned that it would be best to organize the rest of the workshop program when the researchers arrived in Bulgaria, as she thought that they were more efficient and understood each other better when discussing "eyes to eyes."

\section{Collaborative mode}

A few days before the final workshop, the $\mathrm{PhD}$ student arrived in Bulgaria and was able to work with the Bulgarian regional partner and facilitator to better explain the reasoning behind the design proposal and find mutually acceptable solutions. The majority of the proposal was kept, but the largest change was to shorten the workshop to keep the policy makers at the whole meeting. After his arrival a day before the workshop, the French research director had the opportunity to make minor additions to the activity supports, and to check and add questions to the end of process evaluation questionnaire developed by the $\mathrm{PhD}$ student to meet some of their research objectives. The team agreed that all participant groups were to be invited to the flood action-planning workshop by the regional partner, even if the flood component was not their main interest. In this setting, all parties learned more about the perspectives and needs of the others and worked to find more mutually beneficial solutions to the issues discussed.

\section{Further interpretation and ex-post analysis of the negotiation episode}

The ex-post analysis of the Bulgarians' role in the co-design decisions indicates that this was one of the times where the Bulgarians took a much more forthright role in debating the design of the workshop, having learned through the rest of the process. Both the Bulgarians and the researchers believed they could work as equals, which aided the collaboration. This is in stark contrast to the position the Bulgarians took at the beginning of the participatory-modeling process, where the regional partner had stated she did not understand the proposed process, that she had no particular expectations for the results, and that she would give only minimal required support to both the researchers and the Bulgarian facilitator she had hired. Through the process, the regional partner and second facilitator had developed their own objectives for the process, and became stakeholders in its co-design and co-implementation. In their expost interviews, researchers commented that the Bulgarians held the ultimate power of decision over implementation, as the participatory process was carried out in Bulgarian.

\section{Impacts of the negotiation episode}

This negotiation episode, and the decision to implement the action-planning activity in the final workshop, had a number of effects both at the coengineering level and at the stakeholder-planning level (see Fig 1). At the co-engineering level, the negotiation episode enhanced social learning and 
trust among the co-engineers. The Bulgarians' learning focused on the attention required in the design of participatory methods to meet specific objectives, including their own objectives. The external researchers' learning was centered on the needs of the local stakeholders and constraints for providing them, such as the overarching need for further funding and capacity building if any concrete actions were to take place. Trust was built through mutual respect in attempting to achieve both local and scientific objectives and in seeing the achievement of predicted outcomes of the coengineering choices on the planning process.

The impacts of the negotiation episode on the participatory planning process included the development of an action plan for a suite of projects that could be used for structural-funding proposals. The objective of the participants viewing the process at its end as positive was also achieved, as all participants gave positive evaluations of the process in the final questionnaire. From one of the quantitative questions (to which all 28 participants present at the end of this workshop responded on a four-point Likert scale-entirely agree, agree, disagree, or entirely disagree), 15 respondents "entirely agreed" and 13 "agreed" that "the meeting was important and deserved to be held," which was a similar level of positive evaluation to the previous workshops (Daniell 2008). On the qualitative side, positive responses to the question of whether the process had helped manage water in the Iskar Basin included: "Without any doubt, this process is helping the improvement of the whole area. It is a golden chance to discuss and identify the problems and, based on this analysis, the most appropriate and suitable actions and activities can be undertaken." On the researchers' side, the PhD student met all of the objectives she required for her thesis. However, the negotiated change of problem scope meant that several objectives of the AquaStress project were not achieved, as had been predicted by the research director.

\section{DISCUSSION}

We will use these examples of co-engineering negotiations to discuss a number of emergent issues related to an examination of how objectives, conflicts, and social interactions of the members of the co-engineering process influence participatory water-planning processes. We will outline how negotiation theory has promoted insights into the complexity of implementing participatory water management approaches. We will then move to the grounded speculative insights developed from a comparison of a predominantly managementdriven approach, in the Australian case, with a research-driven approach, in the Bulgarian case. Then, we highlight more general insights gained about the importance of the co-engineering process for participatory water management. We will end by presenting further aspects of these processes that could be investigated to increase understanding of co-engineering participatory water management processes.

\section{Key Insights from the Use of Negotiation Theory in Studying Co-engineering Events}

Ten years ago, practitioners and scholars were still investigating what was desired from participatory processes and what methods could be used to achieve these goals (Dovers 2000). Recently, through extensive field-testing of methods, a much better understanding of these issues has emerged, and individual designers have been able to engineer processes to reach their desired outcomes (Hare et al. 2006). However, it remains a challenge to understand what occurs at the traditionally hidden scale where multiple actors with their multiple, and often divergent, goals embark on "co-"engineering participatory processes. To what extent does this "co-" represent "conflict-ridden," "collaborative," "cooperative," or some other form of collective behavior that shapes both the outcomes and eventual success of the participatory management processes being engineered? We have examined this question through the perspective of negotiation theory, which is gaining prominence in water management, to understand and aid conflict resolution (e.g., Priscoli 2003).

The original contribution made by our work is not the use of this theory in the water domain. Rather, it is highlighting the importance of the negotiation that occurs in the co-initiation, co-design, and coimplementation of participatory water management process planning. Many participants and observers of these processes may be largely aware of these coengineering negotiations, but have not made these observations explicit. These negotiations could be considered as the "shadow negotiations" referred to in the business-negotiation literature (Kolb and Williams 2001, Fortgang et al. 2003, Lewicki et al. 2006). The first key insight we wish to stress is that 
to ensure successful participatory water management outcomes, there are two participatory processes to manage: (1) the participatory water management process, and (2) the co-engineering process. It has been our aim to expose the co-engineering-level negotiations in the water management sector.

In our intervention cases, both levels of participatory processes were interorganizational, with participants coming from government, the private sector, and research institutions. Conceptualizing two distinct, but nested, interorganizational participatory processes allows greater understanding of the complexity encountered in the organization of participatory processes. In particular, as the interorganizational members of the co-engineering negotiations are not necessarily those who participate as stakeholders in the participatory planning process, the negotiations have different foci (refer to Fig. 1 and Fig. 2). However, in our intervention cases, we did see a number of examples of feedback among the processes. The change of problem scope in the Bulgarian case to addressing only floods was, for example, linked to a group of stakeholders participating in the water management process, who were able to influence a number of the co-engineers of the process to negotiate a program change on their behalf. We could also see how the estuary manager, who was a stakeholder in the Australian water management process, was not independent of co-engineering the process, and through his negotiations was able to attain his objectives and protect his interests in achieving his planning goals.

Both negotiations outlined here also highlight how uncertainty is created by the dispersion of resources and authority to make decisions in the two levels of participatory processes. The changing relations and learning that result as negotiations and collective work take place also increase uncertainty. Coping with this uncertainty invariably means that flexibility is required to adapt the initial co-design or "participation plan" (Creighton 2005, von Korff et al. 2010) continually throughout the coimplementation phase. Protocols that increase coengineering decision transparency (see Barreteau et al. 2010) and rules for instigating and monitoring changes may be required to manage adaptation and changes in participation plans in a way that avoids disappointment or disempowerment of participating stakeholders, or even co-engineers. A range of evaluation procedures was used after the Australian negotiation to adaptively attempt (Guba and Lincoln 1989, Syme and Sadler 1994) to mitigate the likely impacts of excluding some participants from a workshop that they were originally to attend. However, how this impacts the "external" nature of the evaluator is highly debatable, as the evaluator also became a "co-engineer" in the participatory process implementation.

We also saw from our cases that dynamics such as social learning and the creation of mutually beneficial solutions to problems (BorriniFeyerabend et al. 2000, Ison et al. 2004, Pahl-Wostl and Hare 2004, Harmonising Collaboration Planning Project 2005) also occur at the coengineering level. At this level, it is the perceived divergence in interests about how and why the participatory stakeholder process should be run that creates challenges. We observed on occasion in our negotiations, that one party would attempt to achieve or resolve a problem by dropping an objective or attempt to ignore his or her own issue if he or she was not interested in entering into a tense negotiation or conflict situation. This was observed when the Bulgarian negotiation entered the "accommodating mode," where the Bulgarian regional partner let her own objectives for a process she understood slip to appease the researchers and maintain peace. Distributive-mode negotiations in our co-engineering processes were commonly found to damage relationships in the group, in keeping with what the literature suggests (Ury 1993, Lewicki et al. 2006). Such insights lead us to suggest that negotiation theory could be used to guide more positive resolution of conflicts in future coengineering processes. The ideal would be a collaborative approach to negotiation that results in integrative "win-win" solutions (refer to Fig. 3) for a majority of co-engineers.

\section{Grounded Speculation: Management-driven, rather than Research-driven, Co-engineering of Participatory water management processes}

As we have seen, one of the major differences between the two intervention cases was that from the co-initiation phase, the Australian project was a largely "management-driven process" with a specific output goal designed to improve estuarine management: the LHEMP plan. In contrast, the Bulgarian project was a largely "research-driven process," with research objectives rather than specified operational or management goals. These key drivers were found to have important impacts on the two processes. 
In the management-driven Australian case, the estuary manager was able to keep the co-engineers focused on the goal of developing an accepted estuary management plan. This clear focus meant that the common interest and need to collaborate in finding a solution appeared in a number of cases to outweigh the individual interests and divergent objectives of some of the co-engineers for the participatory process, as evidenced in the negotiation where some initial interests of the consultant and researcher were not preserved, yet the management goal was achieved.

In the research-driven Bulgarian process, not all coengineers shared or even understood the research objectives. From the beginning of the participatory stakeholder process, the co-engineers were mainly task-focused on implementing the participation plan, rather than focused on a mutual goal or specific outcome for the process. As local stakeholders developed their own ideas on what the process could provide for them, conflicts started to arise in the coengineering group between the protection of different research interests and local stakeholder interests. The divergence of objectives for the process appeared to be compounded by the twopoled leadership structure and dispersion of resources and authority between the Bulgarian regional partner and the external research director, and the fact that participation was carried out in Bulgarian. This persisted until a strongly promoted vision of what the process could provide to stakeholders was developed late in the process. The new operational management objective provided a positive focus for the co-engineering group at the end of the process. This locally appropriated operational objective saw power of decisions being transferred more clearly to the Bulgarians. In particular, this appropriation was aided by the language barrier, as the Bulgarians had to be responsible for all the implementation tasks carried out in Bulgarian.

We have observed that external researchers participating in co-engineering processes are often hesitant to relinquish power over participatoryprocess design and implementation to locals with little knowledge of participatory-process design and skill levels in facilitation, as they believe it may jeopardize the effective implementation of their idealized processes. Therefore, for other researchdriven processes that aim to enhance skills transferal and local capacity building, we see that language barriers can play a positive role in forcing power- sharing arrangements to occur that benefit local populations. Of course, researchers could also attempt to promote similar power-sharing arrangements with local communities in the absence of a language barrier, which might prove even more beneficial for everyone involved.

Although the participatory-process literature shows that positive processes can be driven either by researchers or management officials (e.g., Food and Agriculture Organization 2005), we consider that if operational management actions are a key goal of a process, it would be particularly useful to have a manager with funding potential or executive decision-making authority taking part as a key player or even leader of the co-engineering group. On the other hand, if sharing perceptions and social learning are key aims, then research-driven coengineering processes may be more appropriate until trust between the stakeholders and clear management goals can be developed. Such differences are also demonstrated by types of participatory-modeling processes, where, for example, the more management-driven "sharedvision planning" approach (Palmer et al. 1993, Werick 2000) has clear instrumental goals and the typically research-driven "companion-modeling" approach (Bousquet et al. 1996, D'Aquino et al. 2002, Barreteau 2003) focuses more heavily on social learning (Daniell et al. 2006a). This highlights the importance of the makeup and individual goals of the co-engineering group members and the negotiation on what types of participatory processes and methods may be required to achieve them.

\section{Further Speculative Insights and Areas for Future Research}

From our interventions, it has become clear that as participatory forms of water planning and management become more prevalent, new centers of power are emerging. Negotiations take place among a number of actors who are not necessarily stakeholders in the local water management situation. Each one would like to "engineer" (Dandy et al. 2007) the participatory processes for water management in a manner to achieve their goals. We found that there are typically a number of key actors with diverse skills, as well as institutional and cultural backgrounds, who play multiple roles through the co-engineering process. These key coengineers are also linked to extended networks of 
other actors who influence the negotiations of this core group. Visible participants in these coengineering networks who took on at least one role numbered 15 in the Australian case and 30 in the Bulgarian case, highlighting the truly participatory and complex nature of co-engineering processes. Whether this complexity could be effectively reduced, and whether this would be as desirable as some team-management literature suggests (e.g., Katzenbach and Smith 2002, Gratton and Erickson 2007) would be a useful topic for future research. What was observed from both processes was that more conflicts took place when project team members played the same roles. Whether the coengineering that resulted was more constructive conflict (see Eisenhardt et al. 1997) that added to the quality and results of the process, or was destructive, is difficult to ascertain.

The Australian co-engineering group had a more institutionally diverse, pragmatic, and multiaccountable makeup, with the local government manager, private engineering consultants, and university researchers working together. This impacted power relations and resulted in a need to reconcile a greater diversity of requirements and objectives. In particular, the local government manager, on the one hand, had to keep his hierarchy and the elected councilors satisfied and, on the other hand, had to keep the stakeholders content, to ensure future collaborations and funding opportunities. The private consultants had their profit margins and reputation to maintain and enhance, and their client, the local government, to satisfy. The researchers were less accountable to others as they were externally funded, had research objectives to attain, and theoretically less attachment to the context, its stakeholders, and the outcomes. In the Bulgarian context, the key co-engineering group members were mostly from research institutions being funded by the European Commission to carry out the Iskar project. However, there was a much greater cultural and linguistic diversity, with French, Bulgarian, English, German, and Australian researchers working together.

Linked to these characterizations of diversity in our two cases, as well as those from the literature (e.g., Page 2007), we would suggest that diversity and creative tension among project group members internal and external to the water management system provided the necessary opportunities for innovation and collective knowledge creation required to manage complex adaptive systems, even though this increased the need for more concerted efforts in also managing the co-engineering process. In both processes, natural leaders appeared to emerge, but the leadership was never made explicit in the co-engineering groups. Further investigation into how and to what extent these leaders were effective in developing the teams' and networks' performance, using theory from the management and leadership literature (Bass and Avolio 1994, Jackson and Stainsby 2000, Katzenbach and Smith 2002, Gratton et al. 2007), could yield further insights into co-engineering processes. Then, what models of co-engineering groups appear to be the most effective in promoting effective participatory water management outcomes, in other words who "should" participate in which roles in coengineering processes, could be investigated. We also wonder if, in future processes, another level of participatory management, that is, a "coengineering" of the co-engineering process, and hence the use of specialized participatory methods, could be used to work more effectively with this coengineering group diversity.

\section{CONCLUSION}

We have introduced and outlined the concept of a co-engineering process and how it can have key impacts on the process and outcomes of participatory water management, as well as its indirect capacity to affect the complex adaptive water-related systems under management. We showed through transdisciplinary literature analysis that some research and information exists on certain phases of the co-engineering process, touching on the co-initiation, co-design, and co-implementation phases of participatory water management processes, but that there appear to be no in-depth or systematic analyses of whole processes of coengineering participatory water management projects. Considering the potential importance of these processes and their absence from the literature, a hybrid form of intervention research and transdisciplinary analyses were collectively undertaken in Australia and Bulgaria to gain insights into them. We examined how divergent objectives and conflicts in the project teams were negotiated, and the consequent impacts of this coengineering on the participatory water management processes. These investigations yielded many insights, including that language barriers may actually aid the process of stakeholder appropriation, collective learning, and skills 
transferal related to the design and implementation of participatory water management processes. In addition, diversity in co-engineering groups, if managed positively through collaborative work and negotiations, can present opportunities, and not just challenges, for achieving a range of desired outcomes for participatory water management processes. It has emerged that further study of coengineering processes represents a new research opportunity. To aid this process, we have outlined a number of future research questions and domainrelated areas, such as examining the role of leadership in co-engineering groups and networks. These areas need to be investigated to begin to better understand the process and impacts of coengineering on participatory water management processes and their targeted complex adaptive social-ecological systems.

Responses to this article can be read online at: http://www.ecologyandsociety.org/voll5/iss4/art11/ responses/

\section{Acknowledgments:}

Thank you to all the participants in the LHEMP and Iskar processes for their time, work efforts, and enthusiasm, and to our colleagues at BMT WBM (Philip Haines, Verity Rollason, Michelle Fletcher), SJB Planning (Michael Baker), HSC (Ross McPherson, Kristy Guise), UACEG (Petar Kalinkov, Svetlana Vasileva, Galina Dimova, Anna Denkova), and Cemagref (Géraldine Abrami) for their support, work, and management in the projects. The Bulgarian part of this work was financially supported by the European Commission, Sixth Framework program, AquaStress Project, GOCE Contract No. 511231-2. The contents of this paper are the sole responsibility of the authors and can under no circumstances be regarded as reflecting the position of the European Union. The lead author would like to acknowledge that this paper has been written as part of the development of her PhD in water management and sustainable development, which was kindly funded by the General Sir John Monash Foundation, the CSIRO (Land and Water), Cemagref (UMR G-EAU) and the Fenner School of Environment and Society at the Australian National University (ANU). The evaluation work carried out by Natalie Jones on the
LHEMP was supported by the ADD-ComMod project, which is funded by the Agence Nationale de Recherche (France). Thank you also to Yorck von Korff, Sabine Möllenkamp, Pieter Bots, Alexis Tsoukiàs, Ariella Helfgott, Carl Folke, and two anonymous reviewers for their useful comments on the earlier versions of this article.

\section{LITERATURE CITED}

Argyris, C., and D. A. Schön. 1996. Organizational learning II: theory, method and practice. Addison-Wesley, Reading, Massachusetts, USA.

Avenier, M.-J., L. Nourry, and M. Sweeney. 1999. Sciences of the artificial and knowledge production: the crucial role of intervention research in management sciences. Design Issues 15:55-70.

Barreteau, O. 2003. Our companion modeling approach. Journal of Artificial Societies and Social Simulation 6. [online] URL: http://jasss.soc.surrey. ac.uk/6/2/1.html.

Barreteau, O., P. W. G. Bots, and K. A. Daniell. 2010. A framework for clarifying "participation" in participatory research to prevent its rejection for the wrong reasons. Ecology and Society 15(2): 1. [online] URL: http://www.ecologyandsociety.org/vol15/ iss2/art1/.

Bass, B. M., and B. J. Avolio, editors. 1994. Improving organizational effectiveness through transformational leadership. Sage Publications, Thousand Oaks, California, USA.

Bellamy, J. A., D. H. Walker, G. T. McDonald, and G. J. Syme. 2001. A systems approach to the evaluation of natural resource management initiatives. Journal of Environmental Management 63:407-423.

Berry, M. 1995. Research and the practice of management: a french view. Organization Science 6:104-116.

BMT WBM. 2007. Lower Hawkesbury Estuary synthesis report. Hornsby Shire Council, New South Wales, Australia. 
Borrini-Feyerabend, G., M. T. Farvar, J. C. Nguinguiri, and V. A. Ndangang. 2000. Comanagement of natural resources: organising, negotiating and learning-by-doing. Deutsche Gesellschaft für Technische Zusammenarbeit (GTZ) and International Union for the Conservation of Nature (IUCN), Kasparek Verlag, Heidelberg, Germany.

Bousquet, F., O. Barreteau, C. Mullon, and J. Weber. 1996. Modélisation d'accompagnement: systèmes multi-agents et gestion des resources renouvelables. In Actes du Colloque international "Quel environnement au XXIème siècle?" Environnement, maîtrise du long terme et démocratie. Abbaye de Fontevraud, France. [online] URL: http://cormas.cirad.fr/pdf/accompag nement.pdf.

Bucciarelli, L. L. 1994. Designing engineers. MIT Press, Cambridge, Massachusetts, USA.

Checkland, P. B. 1981. Systems thinking, systems practice. Wiley, Chichester, UK.

Checkland, P. B., and S. E. Holwell. 1998. Action research: its nature and validity. Systemic Practice and Action Research 11:9-21.

Creighton, J. L. 2005. The public participation handbook: making better decisions through citizen involvement. Jossey-Bass, San Francisco, California, USA.

Council of Australian Governments. 2004. Intergovernmental agreement on a national water initiative. Coalition of Australian Governments. [online] URL: http://www.nwc.gov.au/resources/do cuments/Intergovernmental-Agreement-on-a-nationalwater-initiative.pdf.

D'Aquino, P., O. Barreteau, M. Etienne, S. Boissau, S. Aubert, F. Bousquet, C. Le Page, and W. Daré. 2002. The role playing games in an ABM participatory modeling process: outcomes from five different experiments carried out in the last five years. Pages 334-339 in A. E. Rizzoli, and A. J. Jakeman, editors. Integrated assessment and decision support: proceedings of the First Biennial Meeting of the International Environmental Modelling and Software Society. July 2006. International Environmental Modelling and Software Society (iEMSs), Burlington, Vermont, USA.
Dandy, G. C., R. F. Warner, T. M. Daniell, and D. Walker. 2007. Planning and design of engineering systems. Revised edition. Taylor and Francis, London, UK.

Daniell, K.A. 2007. Community workshop 1 for the Lower Hawkesbury Estuary Management Plan: summary report. Prepared for the Hornsby Shire Council, New South Wales, Australia.

Daniell, K. A. 2008. Co-engineering participatory modelling processes for water planning and management. Dissertation. Australian National University, Canberra, Australia and AgroParisTech, Montpellier, France.

Daniell, K. A., and N. Ferrand. 2006. Participatory modelling for water resources management and planning. Report D3.8.2. Aquastress Integrated Project, European Union Sixth Framework Programme.

Daniell, K. A., N. Ferrand, and A. Tsoukiàs. 2006a. Investigating participatory modelling processes for group decision aiding in water planning and management. Proceedings the International Conference on Group Decision and Negotiation Karlsruhe, Germany.

Daniell, K. A., I. White, N. Ferrand, A. Tsoukiàs, S. Burn, and P. Perez. 2006b Towards an art and science of decision aiding for water management and planning: a participatory modelling process. Proceedings of the Thirtieth Hydrology and Water Resources Symposium Launceston, Australia.

David, A. 2000. La recherche-intervention, cadre général pour la recherche en sciences de gestion? Pages 193-213 in A. David, A. Hatchuel, and R. Laufer, editors. Les nouvelles fondations des sciences en gestion. Vuibert, Collection FNEGE, Paris, France.

Dikov, O., S. Cheshmedjiev, I. Tasseva, and N. Boneva. 2003. Integrated water management in Bulgaria-current state and national priorities. Time Ecoprojects Foundation, Sofia, Bulgaria.

Dovers, S. 2000. Beyond EverythingCare and EverythingWatch: public participation, public policy, and participating publics. Proceedings of the International Landcare 2000 Conference: Changing Landscapes, Shaping Futures Melbourne, Australia. 
Eisenhardt, K. M., J. L. Kahwajy, and L. J. Bourgeois III. 1997. How management teams can have a good fight. Harvard Business Review 75:775.

European Union (EU). 2000. Directive 2000/60/ EC of the European Parliament and of the Council of 23 October 2000. Establishing a framework for community action in the field of water policy. Official Journal of the European Communities 172.

European Union (EU). 2002. Guidance on public participation in relation to the Water Framework Directive: active involvement, consultation, and public access to information. EU, Brussels, Belgium.

Food and Agricultural Organization of the United Nations (FAO). 2005. Asia-Pacific Fishery Commission regional workshop on mainstreaming fisheries co-management 9-12 August 2005, Siem Reap, Cambodia. FAO, Regional Office for Asia and the Pacific. Bangkok, Thailand.

Ferrand, N. 2004. Participative tools in the WFD: what's for? Needs and requirements from HarmoniCOP and HarmoniQUA. HarmoniQUA, 16 November 2004, Copenhagen, Denmark.

Ferrand, N., and K. A. Daniell. 2006. Comment évaluer la contribution de la modélisation participative au développement durable? Séminaire interdisciplinaire sur le développement durable. Lille, France.

Ferrand, N., M. Hare, and J.-E. Rougier. 2006. Iskar test site option description living with flood and drought: methodological document to the Iskar Test Site. Aquastress Integrated Project, European Union Sixth Framework Programme.

Ferrand, N., I. S. Ribarova, K. A. Daniell, J.-E. Rougier, A. Popova, S. Vasileva, and G. Abrami. 2007. Supporting a multi-level participatory modelling process for floods and droughts comanagement. Journées de la Modélisation au Cemagref, Clermont-Ferrand, France.

Fisher, R., and W. Ury. 1981. Getting to yes: negotiating agreement without giving in. Houghton Mifflin, Boston, Massachusetts, USA.
Flood, R. L. 1998. Action research and the management and systems sciences. Systemic Practice and Action Research 11:79-101.

Fortgang, R. S., D. A. Lax, and J. K. Sebenius. 2003. Negotiating the spirit of the deal. Harvard Business Review 81:66-75.

Gratton, L., and T. J. Erickson. 2007. Eight ways to build collaborative teams. Harvard Business Review 85:100-109.

Gratton, L., A. Voigt, and T. J. Erickson. 2007. Bridging faultlines in diverse teams. MIT Sloan Management Review 48:22.

Guba, E. G., and Y. S. Lincoln. 1989. Fourth generation evaluation. Sage Publications, Newbury Park, California, USA.

Hare, M. 2006. Evaluation of process and next steps for the Iskar River Basin Test Site within the AquaStress project. Seecon Report 9. Seecon Deutschland GmbH, Osnabrück, Germany.

Hare, M. P., O. Barreteau, M. B. Beck, R. A. Letcher, E. Mostert, J. D. Tàbara, D. Ridder, V. Cogan, and C. Pahl-Wostl. 2006. Methods for stakeholder participation in water management. Pages 177-225 in C. Giupponi, A. J. Jakeman, D. Karssenberg, and M. P. Hare, editors. Sustainable management of water resources: an integrated approach. Edward Elgar, Chichester, UK.

Harmonising Collaboration Planning Project (HarmoniCOP). 2005. Learning together to manage together: improving participation in water management. University of Osnabrück, Germany. [online] URL: http://www.harmonicop.uos.de/Harm oniCOPHandbook.pdf.

Hatchuel, A. 1994. Les savoirs de l'intérvention en entreprise. Entreprises et Histoire 7:59-75.

Hatchuel, A., and H. Molet. 1986. Rational modelling in understanding and aiding human decision-making: about two case studies. European Journal of Operational Research 24:178-186.

Hong, L., and S. E. Page. 2004. Groups of diverse problem solvers can outperform groups of high- 
ability problem solvers. Proceedings of the National Academy of Sciences of the United States of America 101:16385-16389.

Hornsby Shire Council (HSC). 2006. Q26/2006 Lower Hawkesbury Estuary management plan: tender document. HSC Water Catchments Team, New South Wales, Australia.

Huxham, C., editor. 1996. Creating collaborative advantage. Sage Publications, London, UK.

Institution of Engineers Australia (IEA). 2000. Code of ethics. IEA, Barton, Australia.

Ison, R. L., P. Steyaert, P. P. Roggero, B. Hubert, and J. Jiggins, editors. 2004. The SLIM (social learning for the integrated management and sustainable use of water at catchment scale) final report. European Commission, European Union Fifth Framework Programme.

Jackson, P. M., and L. Stainsby. 2000. Managing public sector networked organisations. Public Money and Management 20:11-16.

Jones, N. A. 2007. Lower Hawkesbury Estuary Management Plan (LHEMP) on-going evaluation report. Prepared for the ADD-ComMod project (La modélisation d'accompagnement: une pratique de recherche en appui au développement durable), Programme 2005 du Agriculture et Developpement Durable en France. Australian National University (ANU) and Australian Commonwealth Scientific and Research Organization (CSIRO), Canberra, Australia.

Jones, N.A., P. Perez, T. G. Measham, G. J. Kelly, P. D'Aquino, K. A. Daniell, A. Dray, and N. Ferrand. 2009. Evaluating participatory modeling: developing a framework for cross-case analysis. Environmental Management 44:1180-1195.

Katzenbach, J. R., and D. K. Smith. 2002. The discipline of teams: a mindbook-workbook for delivering small group performance. Wiley, New York, New York, USA.

Ker Rault, P. A., and P. J. Jeffrey. 2008. Deconstructing public participation in the Water Framework Directive: implementation and compliance with the letter or with the spirit of the law? Water and Environment Journal 22:241-249.
Kimmerikong. 2005. Hawkesbury-Nepean River Estuary Management scoping study: final report. Kimmerikong Pty Ltd. Natural Resource Management, New South Wales, Australia.

Knight, C. G., I. Raev, and M. P. Staneva, editors. 2004. Drought in Bulgaria: a contempory analog for climate change. Ashgate, Aldershot, UK.

Kolb, D. M., and J. Williams. 2001. The shadow negotiation: how women can master the hidden agendas that determine bargaining success. Simon and Schuster, New York, New York, USA.

Kundzewicz, Z. W., and H.-J. Schellnhuber. 2004. Floods in the IPCC TAR perspective. Natural Hazards 31:111-128.

László, E. 2006. The chaos point: the world at the crossroads. Piatkus, London, UK.

Leach, G., and J. Wallwork. 2003. Enabling effective participation, negotiation, conflict resolution and advocacy in participatory research: tools and approaches for extension professionals. Australasian Pacific Extension Forum (APEN) 2003 Forum. APEN, Hobart, Australia. [online] URL: http://www.regional.org.au/au/apen/2003/ refereed/083leachgwallworkj.htm.

Leeuwis, C. 2000. Reconceptualizing participation for sustainable rural development: towards a negotiation approach. Development and Change 31:931-959.

Levin-Rozalis, M. 2004. Searching for the unknowable: a process of detection-abductive research generated by projective techniques. International Journal of Qualitative Methods 3:(2) 1. [online] URL: http://www.ualberta.ca/ iiqm/bac kissues/3 2/pdf/rozalis.pdf.

Lewicki, R., D. Saunders, J. Minton, and B. Barry. 2001. Essentials of Negotiation. McGrawHill, Boston, Massachusetts, USA.

Lewicki, R. J., D. M. Saunders, and B. Barry. 2006. Negotiation. McGraw-Hill International, New York, New York, USA.

March, J. G. 1978. Bounded rationality, ambiguity, and the engineering of choice. The Bell Journal of Economics 9:587-608. 
Marsh, R., G. Rowe, and L. J. Frewer. 2001. A toolkitfor evaluating public participation exercises. Report to the Department of Health and Safety, Institute of Food Research, Norwich, UK.

Midgley, G. 2000. Systemic intervention: philosophy, methodology, and practice. Kluwer/ Plenum, New York, New York, USA.

New South Wales (NSW) Government. 1992. Estuary management manual. NSW Government, NSW, Australia.

Ostanello, A., and A. Tsoukiàs. 1993. An explicative model of 'public' interorganizational interactions. European Journal of Operational Research 70:67-82.

Page, S. E. 2007. The difference: how the power of diversity creates better groups, firms, schools and societies. Princeton University Press, Princeton, New Jersey, USA.

Pahl-Wostl, C., and M. Hare. 2004. Processes of social learning in integrated resource management. Journal of Community and Applied Social Psychology 14:193-206.

Palmer, R. N., A. M. Keyes, and S. Fisher. 1993. Empowering stakeholders through simulation in water resources planning. Pages 451-454 in $\mathrm{K}$. Hon, editor. Water management in the '90s: a time for innovation. American Society of Civil Engineers (ASCE) Annual Conference, 1-5 May 1993, Seattle, Washington, USA.

Pease, A., and B. Pease. 2005. The definitive book of body language: how to read others' thoughts by their gestures. Orion, London, UK.

Priscoli, J. D. 2003. Participation, consensus building, and conflict management training course (tools for achieving PCCP). IHP-IV technical documents in hydrology. PC->CP Series, No. 22. World Water Assessment Programme (WWAP), UNESCO International Hydrological Programme (IHP), Paris, France.

Pritchard Jr., L., and S. E. Sanderson. 2002. The dynamics of political discourse in seeking sustainability. Pages 147-169 in L. H. Gunderson, and C. S. Holling, editors. Panarchy: understanding transformations in human and natural systems. Island, Washington, D.C., USA.
Ribarova, I., D. Assimacopoulos, A. Balzarini, N. Ferrand, J.-E. Rougier, M. Hare, D. Inman, K. Tarnacki, L. Vamvakeridou-Lyroudia, and T. de Vries. 2006. AquaStress case study Iskar: report of the Joint Work Team (JWT). Presented to the Project Steering Group (PSF), 29th June 2006, Brussels, Belgium.

Rougier, J.-E. 2006. Quelles modalités de participation des acteurs à la gestion locale de l'eau? Réflexion sur trois cas européens. Thèse Professionnelle. Institut Supérieur d'Ingénierie et de Gestion de l'Environnement, Montpellier, France.

Siebenhüner, B., and V. Barth. 2005. The role of computer modelling in participatory integrated assessments. Environmental Impact Assessment Review 25:367-389.

Standards Australia. 2004. AS/NZS 4360:2004, risk management, and companion handbook $H B$ 436:2004. Standards Australia, Sydney, Australia.

Standards Australia. 2006. HB 203:2006, Environmental risk managementL: principles and processes. Standards Australia, Sydney, Australia.

Syme, G. J., and B. S. Sadler. 1994. Evaluation of public involvement in water resources planning: a researcher-practitioner dialogue. Evaluation Review 18:523-542.

Thomas, K. W. 1976. Conflict and conflict management. Pages 889-935 in M. D. Dunnette, editor. Handbook of industrial and organizational psychology. Rand McNally, Chicago, Illinois, USA.

Thomson, A. M., and J. L. Perry. 2006. Collaboration processes: inside the black box. Public Administration Review 66:20-32.

Tsoukiàs, A. 2007. On the concept of decision aiding process: an operational perspective. Annals of Operations Research 154:3-27.

Ury, W. 1993. Getting past no: negotiating with difficult people. Bantam, New York, New York, USA.

Vasileva, S. 2007. Technical evaluation report for the Iskar test site, Bulgaria. Aquastress Integrated Project, European Union Sixth Framework Programme. 
von Korff, Y., P. d'Aquino, K. A. Daniell, and R. Bijlsma. 2010. Designing participation processes for water management and beyond. Ecology and Society 15(3): 1. [online] URL: http://www.ecology andsociety.org/vol15/iss3/art1/.

Werick, W. 2000. The future of shared vision planning. In R. H. Hotchkiss, and M. Glade, editors. American Society of Civil Engineers 2000 Joint Conference in Water Resources Engineering and Water Resources Planning and Management, Minneapolis, Minnesota, USA.

Yin, R. K. 2003. Case study research: design and methods. Third Edition. Sage Publications, Thousand Oaks, California, USA. 


\section{APPENDIX 1: LITERATURE REVIEW ON CO-ENGINEERING PARTICIPATORY WATER MANAGEMENT PROCESSES}

We will systematically work backwards through the co-engineering phases, highlighting the literature and insights relevant to the co-implementation, co-design and co-initiation phases. To our knowledge, the term, co-engineering, has never been applied to multi-stakeholder or participatory water planning and management processes. However, the term can be found in other domains such as information technology or manufacturing sectors, but often as a contraction of "concurrent engineering" with a focus on process timing, rather than the "collective" work practices with a focus on relations. We have found that the insights related to our co-engineering scale of analysis are scattered through an extraordinarily diverse range of literature. One of the current difficulties in advancing knowledge on research areas which require trans-disciplinary forms of analysis, relates to difficulties in understanding or critically appreciating the ideas behind a range of disciplinary vocabularies and thus locating relevant research (Bammer 2005).

\section{Co-implementation}

The largest bodies of literature related to co-engineering participatory water management processes tend to focus on the (co-)implementation phase of participatory water management processes. Most papers on participatory modeling and its variants in water management such as Palmer et al. (1993), Hare et al. (2003), Pahl-Wostl and Hare (2004), Dray et al. (2005) and many in this special feature fit into this category, yet they rarely focus on the relational dimension of project teams during the implementation process. One quality exception stems from systems dynamics literature, where the roles and interactions that appear beneficial in the co-implementation phase for group model building using system dynamics models, have been outlined (Richardson et al. 1992, Andersen and Richardson 1997, Luna-Reyes et al. 2006). However, as all of this literature is based on the use of one type of method, issues of how method choice in project teams occurs is outside the scope of these works. Broader views on the topic are found in adaptive co-management literature (Berkes and Folke. 1998, Olsson et al. 2004) or in multi-stakeholder platform literature (e.g., Fayesse 2006). These views provide some relevant reflections for our study of co-engineering systems. Some of the most relevant insights on project team roles that even touch on some aspects of design and initiation, as well as the co-implementation process, are present in Levrel and Bouamrane (2008), Kelly (2001) and Bots (2008). One perspective on both the operational and relational aspects of the co-implementation part of the process is outlined by Bouwen and Taillieu (2004) in their paper on multi-party collaborations in the natural resources sector.

\section{Co-design}

Recent research on the design phase often focuses on ways to select, and to an extent to evaluate, participatory methods and tools in a given context (Rowe and Frewer 2000, Beierle and Cayford 2002, Lynham et al. 2007, Mazri 2007, Bayley and French 2008). However, rather than determining how to best fit the available approaches to the context, some researchers recognize the need for increased theoretical and practical understanding on how and what types of participatory structures could be conceived or designed to best deal with specific contextual problem constraints. This challenge has been addressed in part through the operational research literature, including the meta-design framework laid out in the System of Systems Methodologies (Flood and Jackson 1991) and subsequent approaches such as Multi-methodology (Mingers 2001, 2003) or the Creative Design of Methods (Midgley 1997a, b, 2000). Further information on the design phase, including issues of process planning, stakeholder analysis and decision analysis (Creighton 2005), is covered in Von Korff et al.(2008) but without emphasis on the collective aspects.

Following Churchman's (1968) introduction of the co-design concept, Ulrich $(1983,1991)$ and Midgley (2000) have focused their work on further uncovering normative premises and making explicit the boundary judgments of various stakeholders in design processes where boundary judgments "define what constitutes "content' in any particular process" and lead to "distinctions of what exists" and the concepts of inclusion and exclusion (Midgley 2000). Despite the fact that their co-design processes often refer to our coimplementation phase (see Fig. 2), some of their insights on the relational aspects may still be applicable to our interest in the design of policy-level systems. Other enquiries into the interactions between cooperation and design can be found in a number of domains, including the management sciences (e.g., Nonaka and 
Takeuchi 1995, De Terssac and Friedberg 2002, Bouzon 2004, Fuchs 2004, Hatchuel 2004, Kolfschoten et al. 2004, Kazakçi and Tsoukiàs 2005), ergonomy (e.g., Gaillard and Lamonde 2001), sociology of work and science (e.g., Vinck 1999, Callon et al. 2001) and policy and institutional analyses (e.g., Ostrom 1990, 1996, Edelenbos 1999, Enserink and Monnikhof 2003, Bots 2007), and these could inform our analyses.

\section{Co-initiation}

Research that focuses on the co-initiation stage of participatory processes is most commonly found in public administration, policy or development studies. For example, some articles linked to change and development studies in a range of domains such as co-management, urban planning and education program development, have started to show some of the roles that development workers, governments, researchers, NGOs, and other institutional actors play in setting up and influencing participatory processes (e.g., Sundar 2000, Watson 2000, McKinnon 2007, Helfgott 2008). However, there appears to be relatively little research specifically linked to different types of co-initiation structures which are used to set up and aid participatory water management processes.

\section{The whole co-engineering process}

A handbook for co-management interventions developed by Borrini-Feyerabend et al. (2000) takes a more operational approach to outlining the phases required. Their operational phases, entitled "a point of departure", "organizing for the partnership" and "negotiating plans and agreements", provide an example of typical co-engineering process phases, although the relational issues and interactions required or expected between project team members are not a major focus. Similarly, a number of other reports on developing processes and tools to support social learning in water management (e.g., Ison et al. 2004, HarmoniCOP 2005) and guides on building broad scale public participation programs (e.g., Leeuwis 2000, Wiedemann et al. 2000, Bertrand and Martel 2002, Creighton 2005, CEAA 2008) outline phases or questions to be considered in participatory process engineering. However, most still lack insights or questions related to the management of the relational aspects of the project teams and stakeholders involved. For such relational aspects of project teams some relevant literature is available in policy development and strategy building (e.g., PMSU 2004), organizational and engineering management (e.g., Dandy et al. 2007), negotiation and conflict management (e.g., Thomas 1976, Fisher and Ury 1981, Leeuwis 2000, Lewicki et al. 2001, Leach and Wallwork 2003, Rinaudo and Garin 2003), or leadership, teamwork, organizational or social psychology literature (e.g., Senge 1990, Bass and Avolio 1994, Schein 1999, Katzenbach and Smith 2002, Stewart 2008), where there is a much stronger tradition of using negotiation and team building theory linked to appreciating personality and skill differences required for effective relational and operational management. Systematic evaluation of co-engineering processes also appears rare, although elements of qualitative description of such processes is present in a few articles, some of which do not focus specifically on participatory water management processes (e.g., Syme and Sadler 1994, Berry 1995, Midgley 2000, Creighton 2005).

\section{LITERATURE CITED}

Andersen, D. F., and G. P. Richardson. 1997. Scripts for group model building. System Dynamics Review 13:107-129.

Bammer, G. 2005. Integration and implementation sciences: building a new specialization. Ecology and Society 10(2): 6. [online] URL: http://www.ecologyandsociety.org/vol10/iss2/art6/.

Bass, B. M., and B. J. Avolio, editors. 1994. Improving organizational effectiveness through transformational leadership. Sage Publications, Inc., Thousand Oaks, California, USA.

Bayley, C., and S. French. 2008. Designing a participatory process for stakeholder involvement in a societal decision. Group Decision and Negotiation 17:195-210.

Beierle, T. C., and J. Cayford. 2002. Democracy in practice: public participation in environmental decisions. Resources for the Future, Washington, D.C., USA. 
Berkes, F., and C. Folke., editors. 1998. Linking social and ecological systems: management practices and social mechanisms for building resilience. Cambridge University Press, Cambridge, UK.

Berry, M. 1995. Research and the practice of management: a French view. Organization Science 6:104-116.

Bertrand, L., and J.-M. Martel. 2002. Une démarche participative multicritère en gestion integrée des forêts. INFOR (Information systems and operational research) 40:223-239.

Borrini-Feyerabend, G., M. T. Farvar, J. C. Nguinguiri, and V. A. Ndangang. 2000. Co-management of natural resources: organising, negotiating and learning-by-doing. GTZ and IUCN, Kasparek Verlag, Heidelberg, Germany.

Bots, P., R. Bijlsma, Y. von Korff, N. van der Fluit, and H. Wolters. 2010. Supporting the constructive use of existing hydrological models in participatory settings: a set of "rules of the game." Ecology and Society, in press.

Bots, P. W. G. 2007. Design in socio-technical system development: three angles in a common framework. Journal of Design Research 5:382-396.

Bouwen, R., and T. Taillieu. 2004. Multi-party collaboration as social learning for interdependence: developing relational knowing for sustainable natural resource management. Journal of Community and Applied Social Psychology 14:137-153.

Bouzon, A., editor. 2004. La place de la communication dans la conception de systèmes à risques. L'Harmattan, Paris, France.

Callon, M., P. Lascoumes, and Y. Barthe. 2001. Agir dans un monde incertain: essai sur la démocratie technique. Seuil, Paris, France.

Canadian Environmental Assessment Agency (CEAA). 2008. Public participation guide. CEAA, Government of Canada, Ottawa, Ontario, Canada. [online] URL: http://www.aceeceaa. gc.ca/012/019/index e.htm.

Churchman, C. W. 1968. The systems approach. Dell, New York, New York, USA.

Creighton, J. L. 2005. The public participation handbook: making better decisions through citizen involvement. Jossey-Bass, San Francisco, California, USA.

Dandy, G. C., R. F. Warner, T. M. Daniell, and D. Walker. 2007. Planning and design of engineering systems: revised edition. Taylor and Francis, London, UK.

De Terssac, G., and E. Friedberg, editors. 2002. Coopération et conception. Octares Editions, Toulouse, France.

Dray, A., P. Perez, C. Le Page, P. D’Aquino, and I. White. 2005. Companion modelling approach: the AtollGame experience in Tarawa atoll (Republic of Kiribati) in A. Zerger, and R. M. Argent, editors. MODSIM 2005 International Congress on Modelling and Simulation. Modelling and Simulation Society of Australia and New Zealand, Melbourne, Australia. [online] URL:

http://www.mssanz.org.au/modsim05/papers/dray.pdf.

Edelenbos, J. 1999. Design and management of participatory public policy making. Public Management Review 1:569-576.

Enserink, B., and R. A. H. Monnikhof. 2003. Information management for public participation in codesign processes: evaluation of a Dutch example. Journal of Environmental Planning and Management 46:315-344. 
Fayesse, N. 2006. Troubles on the way: an analysis of the challenges faced by multi-stakeholder platforms. Natural Resources Forum 30:219-229.

Fisher, R., and W. Ury. 1981. Getting to yes: negotiating agreement without giving in. Houghton Mifflin, Boston, Massachusetts, USA.

Flood, R. L., and M. C. Jackson. 1991. Total systems intervention: A practical face to critical systems thinking. Systems Practice 4:197-213.

Fuchs, C. 2004. Knowledge management in self-organizing social systems. Journal of Knowledge Management Practice 5. [online] URL: http://www.tlainc.com/articl61.htm.

Gaillard, I., and F. Lamonde. 2001. Ingénierie concourante et conception collective : point de vue de I" ergonomie. Pages 149-164 in D. R. Kouabenan, editor. Compétances collectives au travail. L'Harmattan, Paris, France.

Hare, M., R. A. Letcher, and A. J. Jakeman. 2003. Participatory natural resource management: a comparison of four case studies. Integrated Assessment 4:62-72.

HarmoniCOP. 2005. Learning together to manage together: improving participation in water management. "Harmonising Collaboration Planning" Project, Europe. [online] URL:

http://www.harmonicop.uos.de/HarmoniCOPHandbook.pdf.

Hatchuel, A. 2004. Du débat public à la conception collective : qu'est-ce qu'une expertise démocratique? In T. Evette, editor. Expertises et projet urbain. Editions de La Villette, Paris, France.

Helfgott, A. 2008. Situating strength-based approaches to community development in a systems thinking context: the Cambodia tales. UK Systems Society Conference 2008: Building Resilience: Responding to a Turbulent World, 1-3 September, Oxford, UK.

Ison, R. L., P. Steyaert, P. P. Roggero, B. Hubert, and J. Jiggins, editors. 2004. The SLIM (social learning for the integrated management and sustainable use of water at catchment scale) Final report. Prepared for the European Commission, FP5, Europe. [online] URL: http://slim.open.ac.uk/objects/Outcomes/SLIM\%20Final\%20Report.pdf .

Katzenbach, J. R., and D. K. Smith. 2002. The discipline of teams: a mindbook-workbook for delivering small group performance. Wiley, New York, New York, USA.

Kazakçi, A. O., and A. Tsoukiàs. 2005. Extending the C-K design theory: a theoretical background for personal design assistants. Journal of Engineering Design 16:399-411.

Kelly, D. 2001. Community participation in rangeland management, RIRDC Publication No 01/118. Rural Industries Research and Development Corporation, Gatton, Queensland, Australia.

Kolfschoten, G. L., R. O. Briggs, J. H. Appelman, and G.-J. de Vreede. 2004. ThinkLets as building blocks for collaboration processes: a further conceptualization. Pages 137-152 in G.-J. de Vreede, L. A. Guerrero, and G. M. Raventos, editors. CRIWG 2004, LNCS Vol. 3198. Springer-Verlag, Berlin, Germany.

Leach, G., and J. Wallwork. 2003. Enabling effective participation, negotiation, conflict resolution and advocacy in participatory research: tools and approaches for extension professionals. Australasian Pacific Extension (APEN) 2003 Forum, Hobart, Australia. [online] URL: http://www.regional.org.au/au/apen/2003/refereed/083leachgwallworkj.htm.

Leeuwis, C. 2000. Reconceptualizing participation for sustainable rural development: towards a negotiation approach. Development and Change 31:931-959. 
Levrel, H., and M. Bouamrane. 2008. Instrumental learning and indicators efficiency: outputs from coconstruction experiments in West African biosphere reserves. Ecology and Society 13(1): 8. [online] URL: http://www.ecologyandsociety.org/vol13/iss1/art28/.

Lewicki, R., D. Saunders, J. Minton, and B. Barry. 2001. Essentials of negotiation. McGraw-Hill, Boston, Massachusetts, USA.

Luna-Reyes, L. F., I. J. Martinez-Moyano, T. A. Pardo, A. M. Cresswell, D. F. Andersen, and G. P. Richardson. 2006. Anatomy of a group model-building intervention: building dynamic theory from case study research. System Dynamics Review 22:291-320.

Lynham, T., W. de Jong, W. Sheil, T. Kusumanto, and K. Evans. 2007. A review of tools for incorporating community knowledge, preferences and values into decision making in natural resource management. Ecology and Society 12(1): 5. [online] URL: http://www.ecologyandsociety.org/vol12/iss1/art5/.

Mazri, C. 2007. Apport méthodologique pour la structuration de processus de décision publique en contexte participatif. Le cas des risques industriels majeurs en France. UFR Sciences des Organisations. Université Paris Dauphine, Paris, France.

McKinnon, K. 2007. Postdevelopment, professionalism, and the politics of participation. Annals of the Association of American Geographers 97:772-785.

Midgley, G. 1997a. Developing the methodology of TSI: from oblique use of methods to creative design. Systems Practice 10:305-319.

Midgley, G. 1997b. Mixing methods: developing systemic intervention. Pages 250-290 in J. Mingers, and A. Gill, editors. Multimethodology: The theory and practice of combining management science methodologies. Wiley, Chichester, UK.

Midgley, G. 2000. Systemic intervention: philosophy, methodology, and practice. Kluwer Academic / Plenum Publishers, New York, NY, USA.

Mingers, J. 2001. Multimethodology-mixing and matching methods. Pages 289-309 in J. Rosenhead, and J. Mingers, editors. Rational analysis for a problematic world revisited: problem structuring methods for complexity, uncertainty and conflict. Wiley, Chichester, UK.

Mingers, J. 2003. A classification of the philosophical assumptions of management science methods. Journal of the Operational Research Society 54:559-570.

Nonaka, I., and H. Takeuchi. 1995. The knowledge-creating company: how Japanese companies create the dynamics of innovation. Oxford University Press, New York, New York, USA.

Olsson, P., C. Folke, and F. Berkes. 2004. Adaptive co-management for building resilience in socialecological systems. Environmental Management 34:75-90.

Ostrom, E. 1990. Governing the commons: the evolution of institutions for collective action. Cambridge University Press, New York, New York, USA.

Ostrom, E. 1996. Crossing the great divide: coproduction, synergy, and development. World Development 24:1073-1087.

Pahl-Wostl, C., and M. Hare. 2004. Processes of social learning in integrated resource management. Journal of Community and Applied Social Psychology 14:193-206. 
Palmer, R. N., A. M. Keyes, and S. Fisher. 1993. Empowering stakeholders through simulation in water resources planning. Pages 451-454 in K. Hon, editor. Water management in the „90s: a time for innovation, ASCE Annual Conference, 1-5 May 1993, Seattle, Washington, USA.

Prime Minister's Strategy Unit. 2004. Strategy survival guide. PMSU, UK Government, London, UK. [online] URL: http://interactive.cabinetoffice.gov.uk/strategy/survivalguide/index.htm.

Richardson, G. P., D. F. Andersen, J. W. Rohrbaugh, and W. Steinhurst. 1992. Group model building. Proceedings of the 1992 International System Dynamics Conference. System Dynamics Society, Utrecht, Albany, New York, USA.

Rinaudo, J.-D., and P. Garin. 2003. An operational methodology to analyse conflicts over water used at the river basin. 54th International Executive Council of ICID, 20th ICID European Conference, Montpellier, France.

Rowe, G., and L. J. Frewer. 2000. Public participation methods: a framework for evaluation. Science, Technology and Human Values 25:3-29.

Schein, E. H. 1999. Process consultation revisited: building the helping relationship. Addison Wesley Longman, Inc., Reading, Massachusetts, USA.

Senge, P. M. 1990. The fifth discipline: the art and practice of the learning organisation. Currency Doubleday, New York, New York, USA.

Stewart, T. A., editor. 2008. Leading high-performance teams. Harvard Business Review OnPoint, Spring, Harvard Business School Press, Boston, Massachusetts, USA.

Sundar, N. 2000. Unpacking the "joint" in joint forest management. Development and Change 31:255279.

Syme, G. J., and B. S. Sadler. 1994. Evaluation of public involvement in water resources planning: a researcher-practitioner dialogue. Evaluation Review 18:523-542.

Thomas, K. W. 1976. Conflict and conflict management. Pages 889-935 in M. D. Dunnette, editor. Handbook of industrial and organizational psychology. Rand McNally, Chicago, Illinois, USA.

Ulrich, W. 1983. Critical heuristics of social planning: a new approach to practical philosophy. Haupt Academic Publishers, Berne, Switzerland.

Ulrich, W. 1991. Critical heuristics of social systems design. Pages 103-115 in R. L. Flood, and M. C. Jackson, editors. Critical systems thinking: directed readings. Wiley, Chichester, UK.

Vinck, D. 1999. Les objets intermédiaires dans les réseaux de coopération scientifique: contribution à la prise en compte des objets dans les dynamiques sociales. Revue française de sociologie XL-2:385-414.

von Korff, Y., P. d'Aquino, K. A. Daniell, and R. Bijlsma. 2010. Designing participation processes for water management and beyond. Ecology and Society. 15(3): 1. online] URL: http://www.ecologyandsociety.org/vol15/iss3/art1/.

Watson, D. J. 2000. The international resource cities program: building capacity in Bulgarian local governments. Public Administration Review 60:457-463.

Wiedemann, P. M., M. Clauberg, P. C. R. Gray, R. Carius, C. Henschel, H. G. Kastenholz, W. Nothdurft, F. Ruff, and H. J. Uth. 2000. Risk communication for companies: thriving and surviving in an age of risk [online] URL: http://www.fz-juelich.de/inb/inb-mut//vdi/vdi bericht e/index e.html. 


\section{APPENDIX 2: FURTHER INFORMATION ON THE CO-ENGINEERING PROCESSES OF THE AUSTRALIAN AND BULGARIAN INTERVENTIONS}

Fig. A2.1 and A2.2 present a range of co-engineering events that took place through the Australian and Bulgarian interventions, including the negotiation episodes outlined in the main body of the paper. Here they are presented in summary form, looking in particular at the perceived impacts of the decision proposal on the ability of each of the key co-engineers to meet their objectives for the participatory water management process. Taking an example from the paper, in first phase of the featured Australian negotiation the consultant proposed to delete the workshops (the first actor on the list made the proposals), as it was perceived to have a strongly positive impact (++) on their ability to manage their busy time table, even though it may have a negative impact on their workload later on (-), hence leading to the $++/-$ notation. This proposed change would likely have a negative impact (-) on the estuary manager's objectives of keeping good relations with stakeholders and having the plan accepted, and strongly negative consequences (--) for the researcher, as she would likely not be able to complete a participatory process case study for her thesis. Negotiation modes and results are then presented, followed by some of the general outcomes of the co-engineering events. The impacts of these events can be analyzed further by looking at the final implemented participatory processes summarized in Appendix 3.

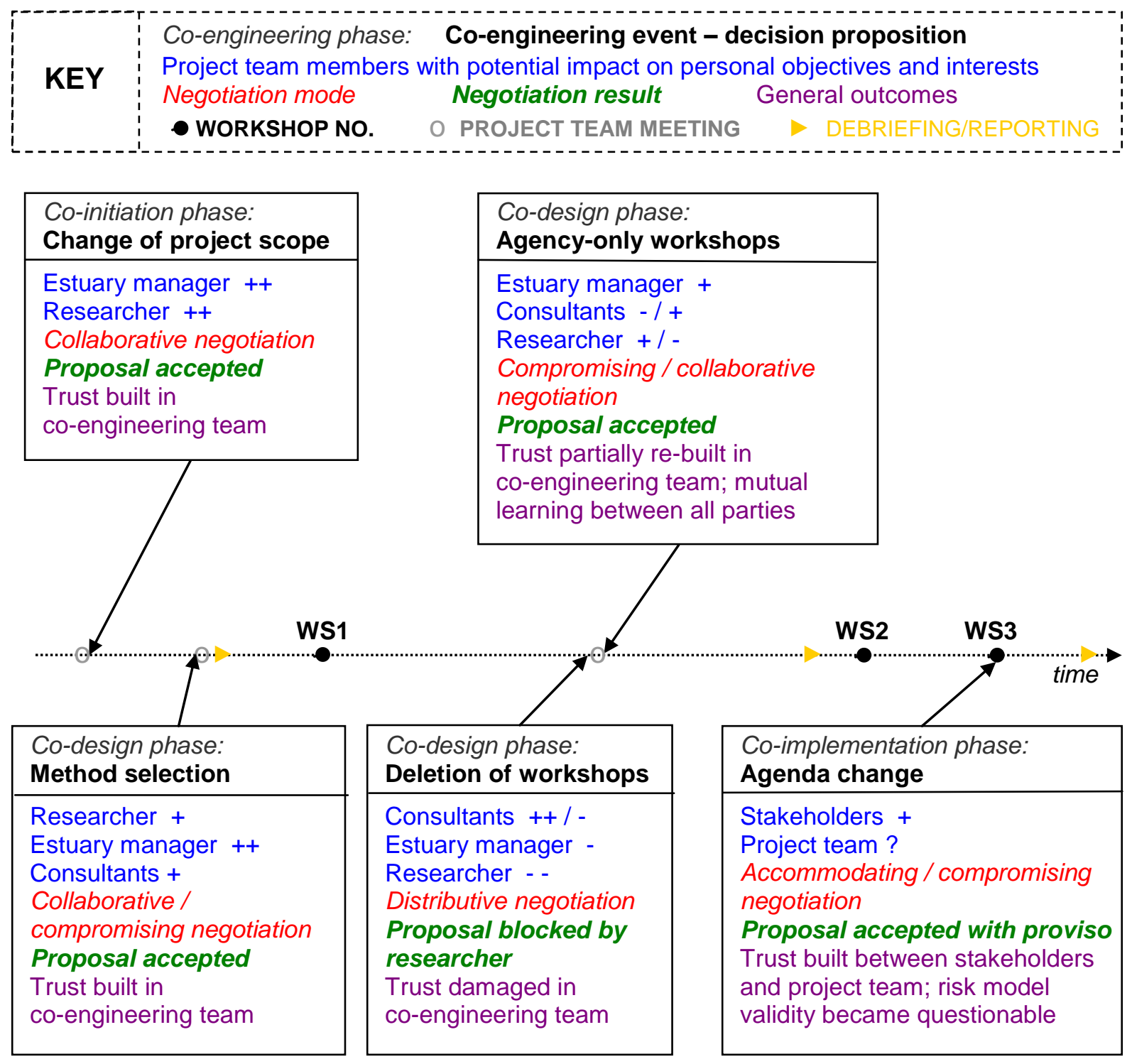

Fig. A2.1. Timeline and summary of principal LHEMP co-engineering events. The scale of potential impacts on each project team member's personal objectives and interests used represents the following: ++ strongly positive; + positive; + / - mitigated (slightly positive); - / + mitigated (slightly negative); - negative; - - strongly negative; and ? unknown. 


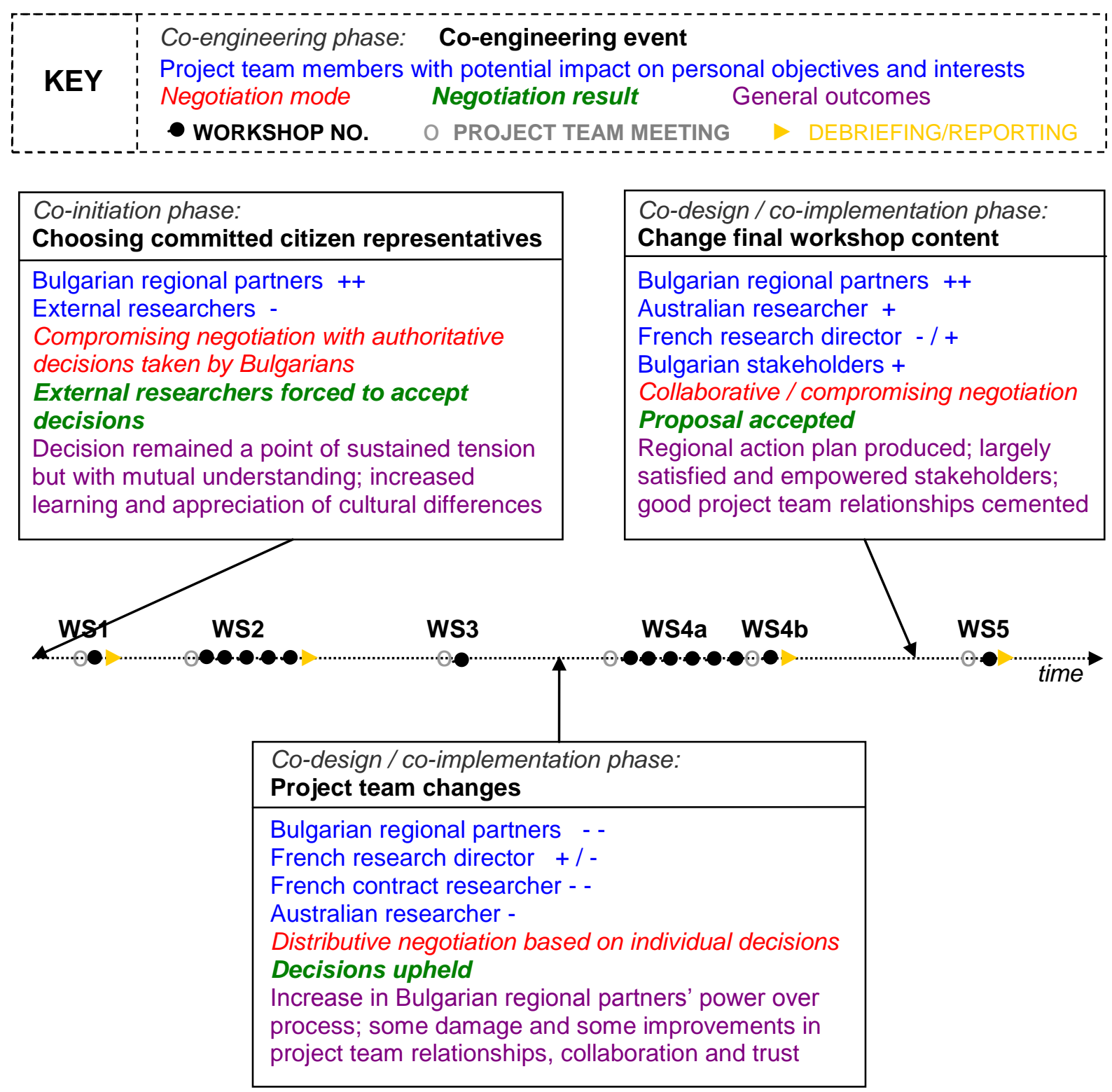

Fig. A2.2. Timeline and summary of principal Iskar co-engineering events. The scale of potential impacts on each project team member's personal objectives and interests used represents the following: ++ strongly positive; + positive; + / - mitigated (slightly positive); - / + mitigated (slightly negative); - negative; and - - strongly negative.

Throughout these co-engineering processes, not only the key group members, but a range of other actors took on co-engineering roles, as summarized in Table A2.1. 
Table A2.1. Comparative role distribution in the co-engineering processes

\begin{tabular}{lcc}
\hline \hline Co-engineering process role & Australia & Bulgaria \\
\cline { 2 - 3 } & Number of people \\
\hline Principle process and method designers & 3 & 5 \\
\hline Facilitators / Mediators & 5 & 9 \\
\hline People playing a significant organizational / logistical role & 9 & 12 \\
\hline People playing a significant assistant technical analysis / modelling role & 6 & 7 \\
\hline People playing a significant role in the evaluation design, implementation and analysis & 3 & 6 \\
\hline Project team members playing all above roles at some stage & 1 & 1 \\
\hline $\begin{array}{l}\text { Total number of people playing at least one role in the co-engineering process } \\
\text { including in project initiation }\end{array}$ & 15 & 30 \\
\hline \hline
\end{tabular}

Note of clarification on participant payments

To encourage participation in the research exercise and offset any inconveniences, the key co-engineers decided that the 60 Bulgarian participants were all to be paid to attend the workshops at a rate that would be sufficiently enticing for them to participate. High government officials were therefore paid at a higher rate compared to the community representatives. Although in some ways this may seem unfair, similarities to the situation in Australia are evident as, even though the 38 participants were not paid by the project team, government officials receive their salaries on days of workshop attendance, whereas many of the community and industry representatives must cover their own costs of participation. Although no comments or complaints were made in either intervention case on this potential inequity, the ethics and resulting impacts of unequal costs of participation in water management processes could prove a valuable future area for research. 


\section{APPENDIX 3: AUSTRALIAN AND BULGARIAN PARTICIPATORY PROCESS SUMMARIES}

\author{
Policy Makers and Managers \\ (State and Local Government \\ representatives, managers of \\ commercial operations, \\ representatives from the Catchment \\ Management Authority and private \\ water supply corporation)
}

\author{
Intermediary Stakeholders \\ (Local government councillors, \\ community associations (i.e. \\ boating, evironmental), local \\ residents (including local \\ scientific experts)
}

\section{Scientific Experts}

(Environmental engineering and planning consultants, university researchers)

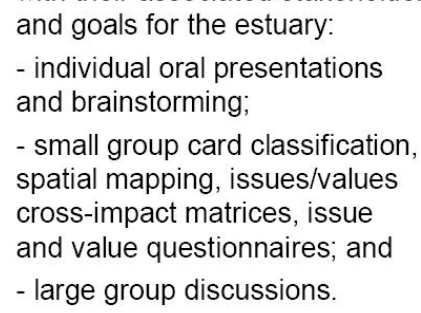

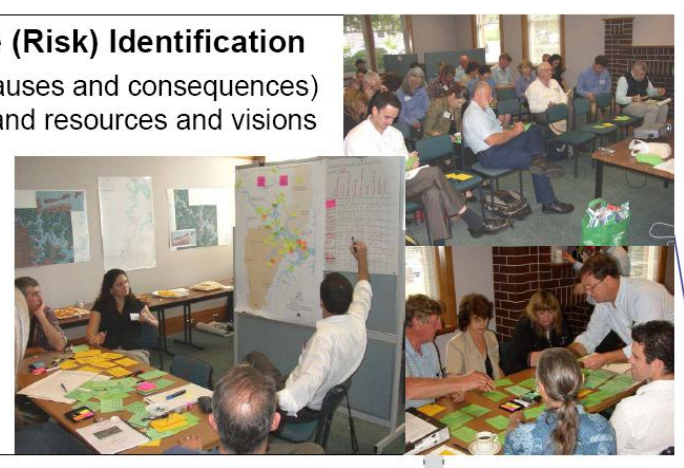

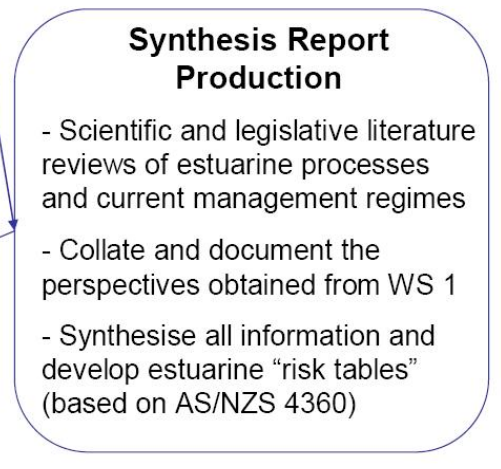
issues) for their consequences on the assets and the associated likelihood of these impacts using the estuarine "risk tables"

- Determine risk level;

- Classify the uncertainty of this prediction; and - Evaluate and prioritise risks

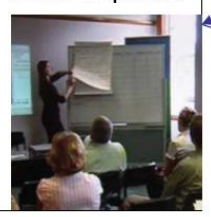

\section{WS3: Risk Treatment}

Define strategies and their associated actions to treat priority risks, as well as stakeholders and resources to carry them out and indicators, monitoring needs and information dissemination strategies to evaluate and improve management

- Strategy Mapping
and preference
distribution
on preferred
actions

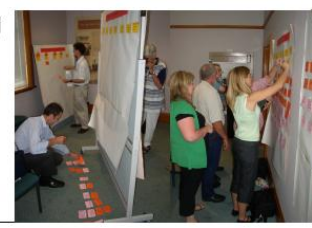

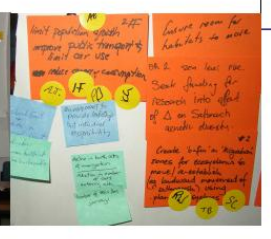

Exhibition of LHEMP for public comment, plan revision, acceptance and implementation

Fig. A3.1. Implemented LHEMP Participatory Management Process 


\section{Policy Makers}

(National Government politicians and bureaucrats, representatives from the River Basin Directorate, private water supply company and international and national NGOs)

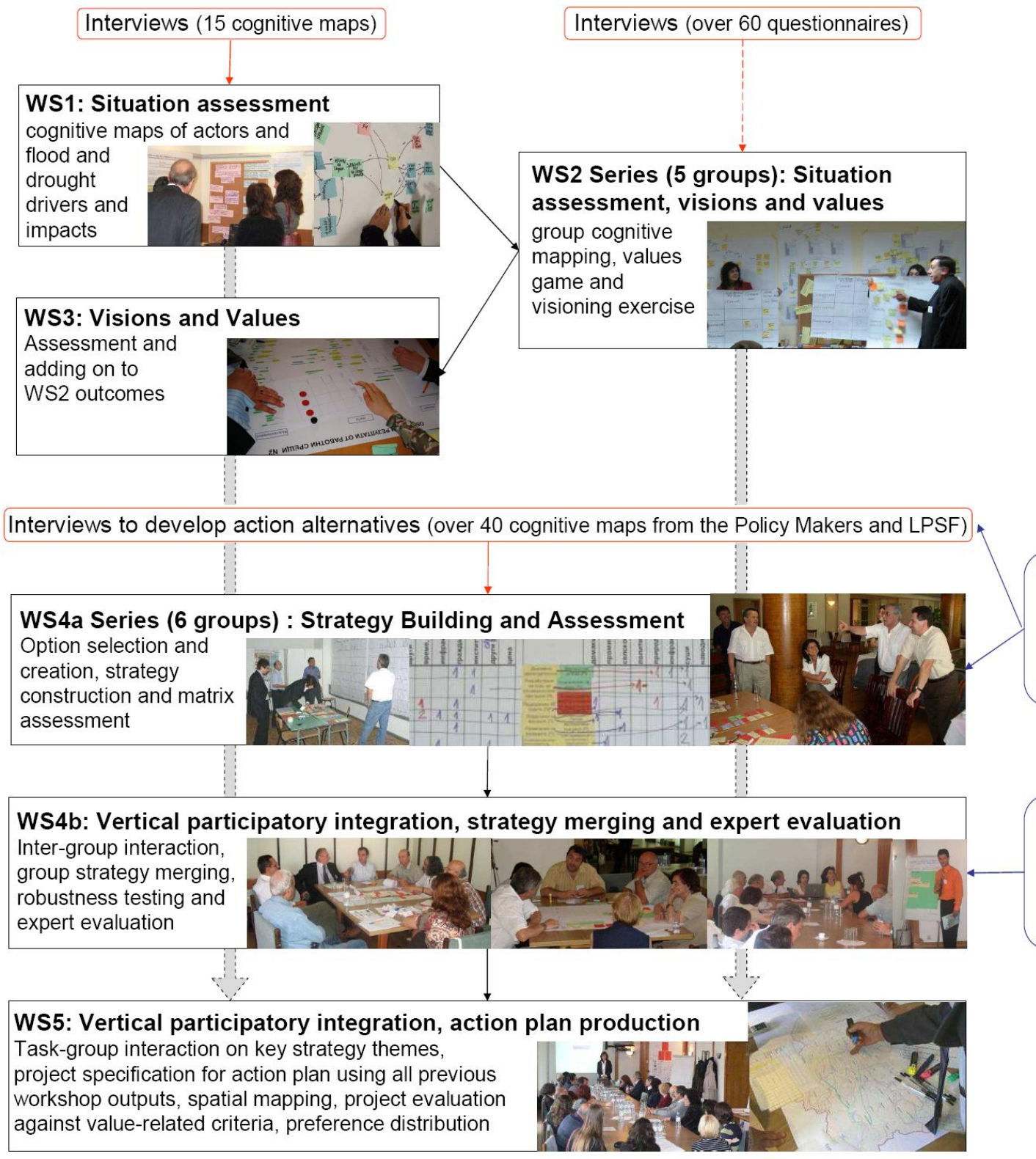

\section{Scientific Experts}

(EU Aquastress

Researchers, local Bulgarian research partners, Bulgarian scientific experts)

Preparation of technical and non-technical options for consideration

Expert "jury" judgements on merged strategies

Fig. A3.2. Implemented Iskar Participatory Management Process 